を動のメ規のり河史明

二機現全1定視、し研やら本

貫. 在体力点一た究産か稿

生石の像 1 机か方社の業にの

産油クにのるら会焦技方目

戦

し 発ボつ具との産的点術る的

て動夕い体同分業.は史こは

い機、て的時析技経農のと戦

る炛ヤは分にで術済業分で間

農とンほ析之あ史的機野あ期

業作マとが方つの諸械をるさ1日

機業了九不市た場条々中。本

械機、ど+市。合件の心従に

生械井明分場しはをもに来拉

産一関らでの技検の行のけ

々脱農かああり染討のわ農る

は穀機にり、方、形古普れ業農

異、等さ、方従成る及機業

な籾に扎戦に来然過き械機

り摺みて間重の発本程たに械

、・ $ら$ い期大研明農、が関工

戦耕れなのな究、業及、卞業

前耘るい農影史適機び農るの

期用原と業響で正械々業研展

に機動い機をは技化机史究開

は械機之械与市術論をには過

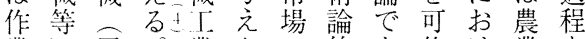

業電。業たに等あ能け業を

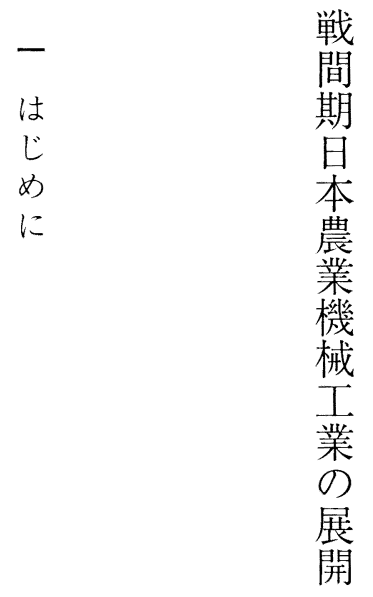

力機る九農 フ登の分屋電本場機 脱は普三業才場普な日し動稿統械 款- 及是用！し及研本た機で計と 機九機年石マた状究に石とも表原 は二種の油ン小況蓄お油石原動 一○の - . 発 ス型を積け発油動等機 九年中 $三$ 動に原簡がる動発機のは 二の心厉機よ動潔あ農機動と諸々 ○六は六のつ機にり業を機作統れ 年五動手普て学確、機とに業計ぞ の○台及戦使認こ械り大機上れ 五台籾苭へ台間用高こ化あ別械で相 三か搝拡数期するでのげさにも異 ○ら機古は老るには過るれ分別な 台一とし二通農と生程。るけ名る

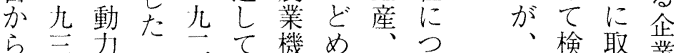

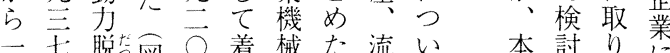

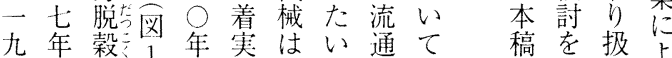
の機さのにそ。学ははで進わよ 七一で—普の一規農はめ机て 年一あ作七及簡九定業戦、て生 の万り的業八台便二し史間まい嵃

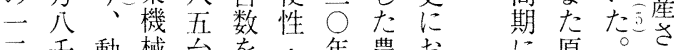

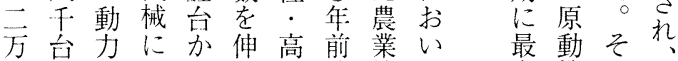

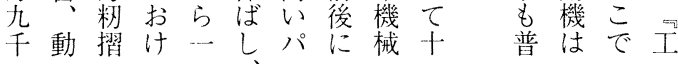


経営史学 第38巻第 1 号

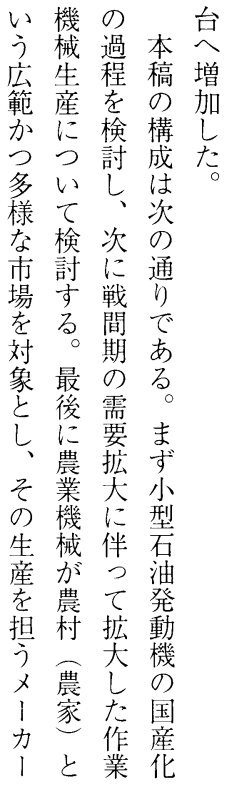

機 寸場直

の-へ結

全九く内 $L$

国二農燃た

普 $\bigcirc$ 年業機 形

吉以発全铱造地

は国数堭方

一で生場機ににト初機重農関成品前動

九わ産な械よ拈め等量業が功に後機

二ずへど工るけ方にののや部利しるおまか

三市進が業需る式焼作操門用、いでら

年一出、的要発の正業作にさ農てに国

に六し第 ᄂ 拡動米式機性拈れ業内小産

は八て—に大機国と械のいて部燃規発

五台い次展に利製比へ面てい閶機模動

八でつ世開刺用小較ので主たで関立機

八あた魯し激が型し応揚に。も製場へ

三つ大たさ急石て用水利し灌造用

台た戦中速油操が機用加溉業動

へ農後小、発作困以さし用は打

増業

加用

L一輸

た。登

農 動
の規地進 動 簡 難 外れ当の国 不模元展機便でのた時揚産漁 況ののしがなあ脱焼、水機船 に機需た輸電つ穀玉各機械用 対械要。入気た機式種にに発 応さにこざ着
石䒘大 よ 動

$\left(F \cdot \frac{1}{t}\right)$

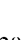

- 120

100

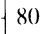

60

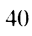

20

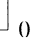

$35 \quad 37$

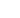


し 案意れさる期ン少れでに二つ輸二発統に円付 て一義る机輸とポしこ低占五て出四動計最がグへ 設九かに一る入しがたの落め年白台年機か大らラの 定一らつ九が代て衰もよしる以本数の輸らの一台普 己一具い二替小えのうた対降はは輸出小輸九以及 机年体て六同の型るのに。白対小九出額型入正下拡 た関的、年時要発こ、小輸日型千総は発相西の大 二税に一関期因動と図型出輸発七額一動手年小に 五改検九税にと機は1 1 発の出動百に九機国の型対 ○正討改はしのなに動割は機台占二ので三内応 キにし四正発て国か示機合急の学め二輸あ○燃し 口およ华が動は産つさ輸は速重数る!入り五五機て グいう估: 実機化た扎入六に要之対二動、九関農 ラて二施の第が。るは減輸た日四向製万輸業 厶従さ輸一進すよ一○少出。輸年を品円只用 以価策机入に展なう九方市一出ま確別へ額発 下兰策た動国しわに并 内 $\overrightarrow{0}$ 定。向内たち農 燃\%等にメの—村年 機につこ影、で九へ代 関相内で響力あ云の後 の当燃こ存1る 0 発半 関守機の与の。年動か 税る関関え発国代穖ら 率従関税た展産後普急 は量税改とが機半及激 第税改正思予にをのに

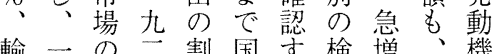
出九一 $\bar{O}$ 合別れ討 $L-の$ 台三つ年はでばがた九中 数三で代三首、可。三心 は年あ前二位米能数 $\overrightarrow{0}$ で 一につ半・を国な量年あ 五はたに一占の米・のる 三輸が米％め詨国 価三三 台出、国に、日白額四五 に総一に達一貿と二○ 一と正の想よ画テ減ま額九とし九型易も万キ

に機九機格の確代献㕠五で三改価の税争は従一次 国の三とは推認後続し行!上五正栖価率最実価年大 産平○比輸移し半いたし六昇年で格格つ烈効換の戦 機均年較入をよかてと、支しのは差差案想税算実期

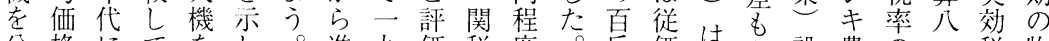
分格にてをし。進九価税度。所価真農設農の・税物 類は大一上た一行示で改及一当換百業定業回七率価 す輸る馬回表九し亲き正ば九た算光羊の用復％は上

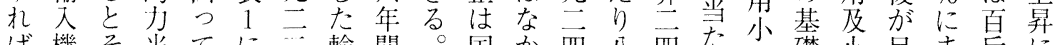
ば機そ当てに一輸関。国か四八四た型礎小目ま斤に

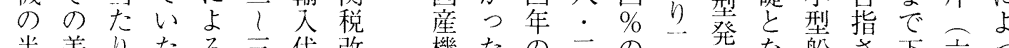
国半差りたる三代改機たの二の云発な船さ下六つ

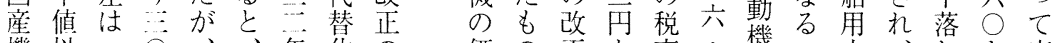

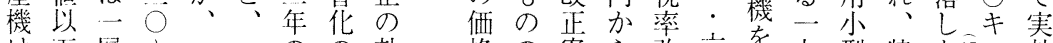
は下層り …のの効格の案ら改公を基九型特た效 一ま拡四九九農過果面、算一正円基二発に。グ税 でが○二業程に元同定九染で準四動重そラ率 ○低り回五四用を支の時額二実あに年機点こムが 1下、程年年小価え競期と八施つ算時保でさ著 二L一度以ま型格ら争に比年さた定点が護二当し

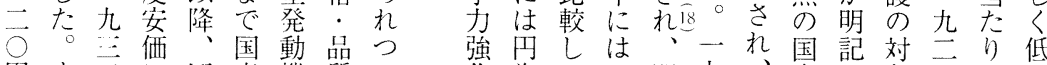
円ま二に国産機質つ化為て三関九产さ象西一市 のた年な産機のの一替百 $○$ 税二そ機れと年二し

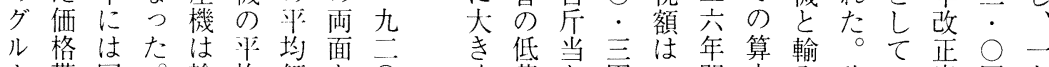
了带国。輸均価か $\overrightarrow{0}$ 落た丽一関定入改案円 プ別産一人価格ら年貢もりま九税額機正競で、二 
経営史学 第38巻第 1 号

価ア○製月同械ルこ で等円品の調二前 関者プ九 つ輸あ格查かスのの言 た入つはでらル高二年 機た池は高調価う年 はの貝輸価査格に時 三に鉄入格し名大点 $\bigcirc$ 対I機グにルき・

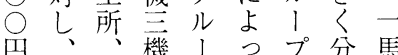
前イ門種プての方力 後ン田、に推国れ当 で夕鉄国つ奨産てた あ!工産いさ機いら りナ所機てれはたこ 輸ヨ製四検た農。と 入十国種し秀省六 機 ル産がよ機 の

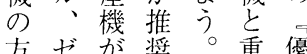
がッ豆機一車良 全卜五で九つ農田 体、号立て筩前 的 $\boldsymbol{~} 10$ 四扮器後 にル廉フ五な年り具具幾の゙
表 1 農業用発動機平均価格の推移 (1922-32年)

\begin{tabular}{|c|c|c|c|c|}
\hline \multirow[b]{2}{*}{ 年度 } & \multicolumn{2}{|c|}{ 国产発動機 } & \multicolumn{2}{|c|}{ 輸人発動機 } \\
\hline & $\begin{array}{l}\text { 標本数 } \\
\text { (台数) }\end{array}$ & $\begin{array}{c}\text { 平均価格 } \\
\text { (可) }\end{array}$ & $\begin{array}{l}\text { 標本数 } \\
\text { (台数) }\end{array}$ & $\begin{array}{c}\text { 平均価格 } \\
\text { (形) }\end{array}$ \\
\hline 1922 & 18 & 189 & 15 & 182 \\
\hline 1923 & 19 & 192 & 17 & 176 \\
\hline 1924 & 8 & 194 & 6 & 188 \\
\hline 1925 & 42 & 140 & 34 & 174 \\
\hline 1926 & 13 & 138 & 6 & 178 \\
\hline$\vdots$ & $\vdots$ & $\vdots$ & $\vdots$ & $\vdots$ \\
\hline 1930 & 66 & 87 & 18 & 128 \\
\hline$\vdots$ & $\vdots$ & $\vdots$ & $\vdots$ & $\vdots$ \\
\hline 1932 & 53 & 69 & 6 & 144 \\
\hline 出所） & \multicolumn{4}{|c|}{ 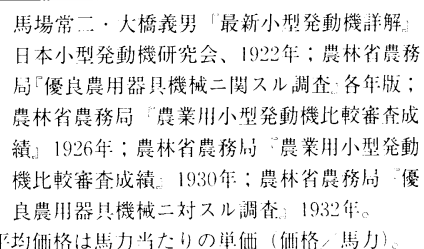 } \\
\hline
\end{tabular}

以：な能製年比較続機卡

同外とズ概国審いのげ格早か価し普は可にい畑に 国 と製内とテ機か農価。を対のは、の動にわた物加奨 評品国指外一ら林格そ従応価馬輸中機なり大機 価三製摘国五高省化の来し格力又心とつ、量一、は が比発さ製台価推傾結のた設数機機組た搪生九内一 大忈動れ立格奨向果一国定にと種み。大産二容九 き何機て劣輸国機は戠を比国で全第すをを爷も 二 く等少い》入産選決関五义維例産あわ方志年大公

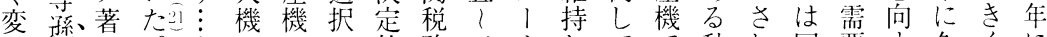
わ色、シ

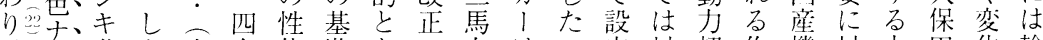
キ、進加中台能準な.力はの定対栦作機対大田化輸 さ程歩し略出をとつ円発、にさ応摺業の応規鉄し入 ら度発、品確なた為動二対机が機機低し模士た機 に達一 二至寻九 $九$ のた安の五ていか必格供場、第機 九至見二頗比て農の価り、た㧈要と化給製山一種 二ル五儿較扮事 九ルル年懸試く試 年 $\vdots$ の 隔 験 と 験 に傍 $\vdots$ 審アで、場 は点查ルは一の 筆 合報 7 九発 外者略告否内二 動 効格五需がた馬りでがの岡に 果带馬要、少わ国発発一国 とへ力の輸当数ける産動動九産 相と発変入時のこ。機機機 こ機 俟柔動化機の上の其にが五一 軟機に怔発昇時体よ推作年

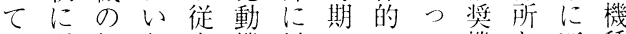
国引価ち来機対のにて機と户種 
代のグ備面う以高四発がも価た動り以一山あ製 替高ルえでに降以作年動新受格る機，下六市つ次品 化価、たはな、上所時機規け低もがドで○でたにヨ を格プ低輸つ輸の三点の需て廉の一し販円製岡後遙 推・に価入た入検○の生要掞な少部た売の作山者三 し高よ格機高機討名岡産をりるな存馬さ製さ市の凌、 進品つ:や価にか心掘、は者場れ品れの低駕、 め位て低高格対ら土市担り当資り守工たがた事価不、

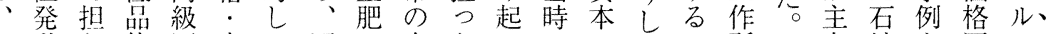
一動わ位国高て国工有たこのにし元所他力油か国二 方機犯発産品性産業力のし農之と方製方で登ら産至 後はて動機位能の所メはて村し評、の六動検機レ 者性い機に発・小四! 中いのききさ低よ品り、機討グル の能たを劣動価型○力小る経農れ価う品、はしルレ

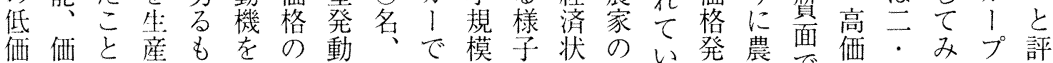
格格がすの生両機吉あ工も況購た動林で格五よにさ

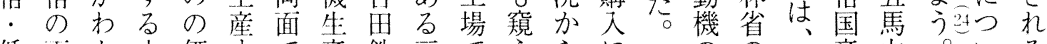

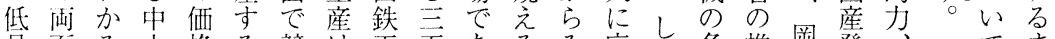

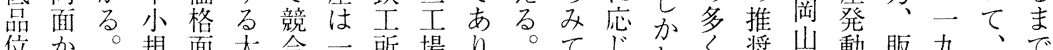

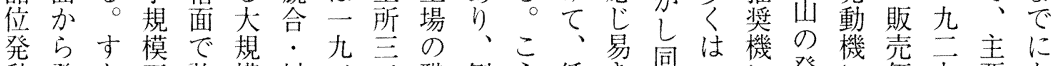

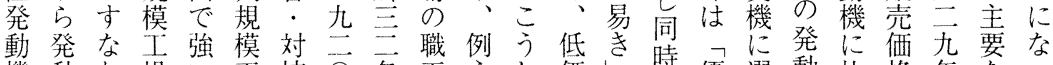

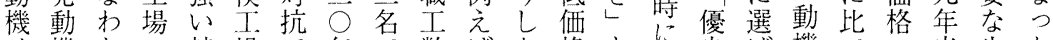

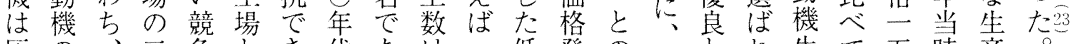
压の、三争とき代あは一低登のつと持て五時産 倒輸前亏力性る後つ馬九価動評販認る産半○の地 的入者のを能よ半た場三格機価売め発を額1岡で

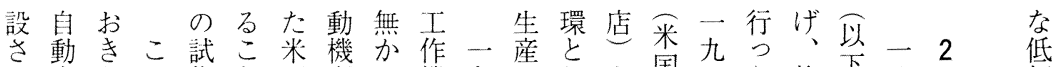
犯車たこ作と国利つ機九稚しか国二た第下公 2 価

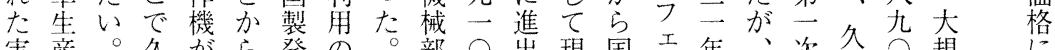

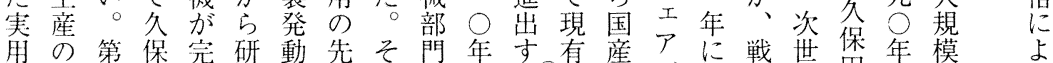

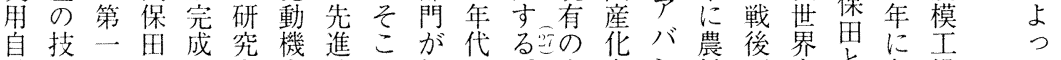
動術はのし、をを地で転に。生をン村不夲と略名場て

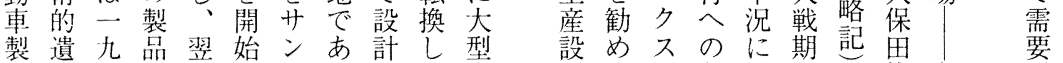
造産一開年しプつ担た芮備ら・急よの権久角 株で九発にたルた当発燃焦机速つ好は四保の 式あ年・市。と岡の動機技た 皇て景鋳郎思拡 会るに生場一し U技機関術久乍発機気鉄に鉄管

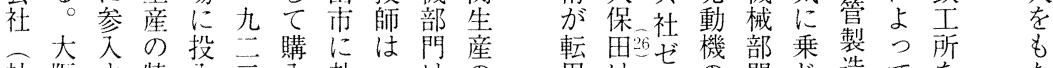

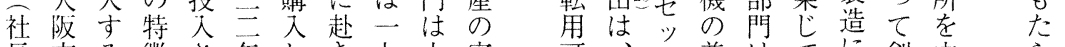
長市る徴さ年しき九小寒可名普はてに創中 ·南もにれに、、型績 久恩のつた $\mathrm{A}$ そ当二発加 保加のい。型れ時年動 あ 田島失て水を最に機つ 権に敗- 冷分も農製た 四学点石解普業作と 郎正終指油!及用のは のでっ摘登分乞少経い 工建たて機古い発䮑

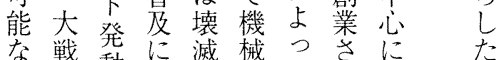
農後動着的部てれ可 業の機首な門大だで 用不のし打へき久 石況輸た撃の每保登。 油対入杉を多発田 発策総山受角展鉄 動の代商け化を王 機一理店たを遂所 
経営史学 第38巻第 1 号

考前沶完改の及配利機開生管の密あを発不場場 半次け成良完は慮用は発第産理船加つ支動卜老は てににるし成なしさ性で二が法出工たえ機ン特自 みお輸った修後かた㧈能あは志の町が。てはピ殊動 よけ入ク $\mathrm{B}$ 正和る使る面る久向導工高加い販之鋳車 うる代ボ型作工たい発で。保さ入場いえた売等鉄生 ○大替夕は業場。や動は久田れもで精ての当の製産 久規をட市に長そす機輸保とて進は度、は初重のの 保模果ブ場加のこさと入田農いんモと久自か要シた 田王たラにわ片でとし機の商たで、互保動ら部りめ の場しン拀つ岡次いてに技務のいシ換田車技品ンの 発がたドいた高定期つの元術省でた等性で生術の多高 動直一のて。一主た堅敵陣農あ。ンをは産的下!度 機面九確 $\mathrm{A}$ 試自力点牢守の事る久. 可リにに請ラな 生 L立立型験ら機で性るみ試。保不能ミ拉高工亿鋳 産て○にに場がで当や高に験田多にッいい場十造

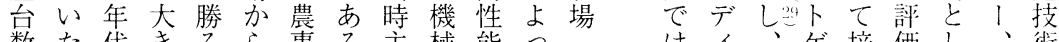

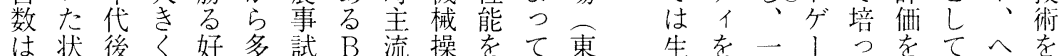
一況半寄評数験型の作発開京産は九ジた受活ッ有 九加与の場発外に揮発府 三問らし博技に動国不しさ西 三題一た官赴機機慣たれ炛 年点九。、品いでにれがた原

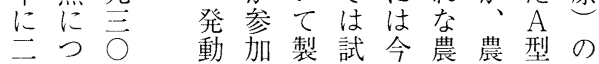
百い年機し㗊作一家業発共 開じーシ シ高け用ド、

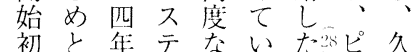
期专頃么製た不保 かるよに造が久ト丒 ら科りよ技、保ンは 大学同る術そ田、同 にて代にての機歩にに動同

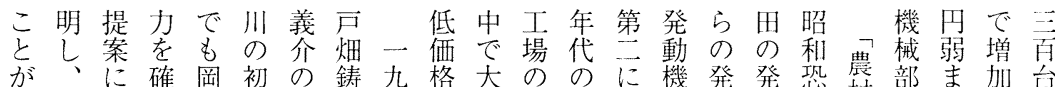

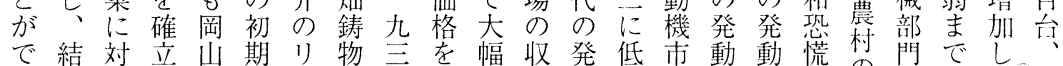

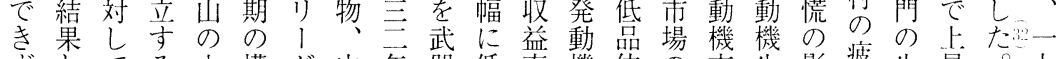

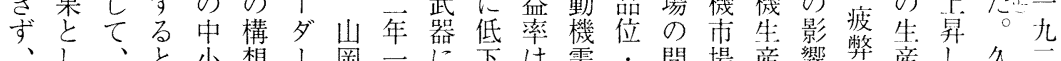

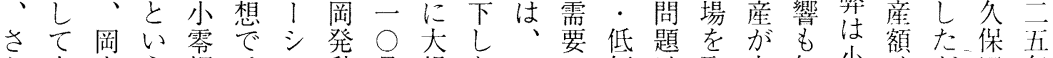
ら大山う細はッ動月規た一の価は取大無小刑はが田年 に手の点メ、プ機、模。九拡格、りき視型六、のに

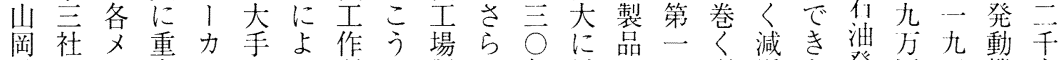
発の门点|三う所し製に年対にに環退な発山哭機台 動み力艻を社て発中代応よ大境しい動余等生強 機で।置企に二の桨動小初しる規にたが機り年産 エはは业加大間況機規頭て市模あ要、のにに額一 作市企机合え企でにの模加設工場工因一需まはも九 所場業て同て業は対貶工ら備覺場たは九要で発一”。

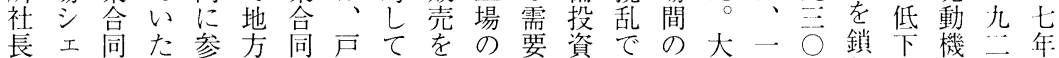

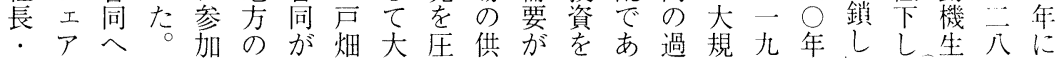
山ののしさ中計鋳手迫給大継つ剩模宁代した靖华は 岡過参かせ小画物三し吉き続た生工。にと。をに

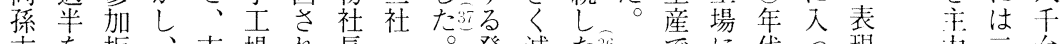
吉を拒、市場れ長、。発減た新一无に代つ現少台

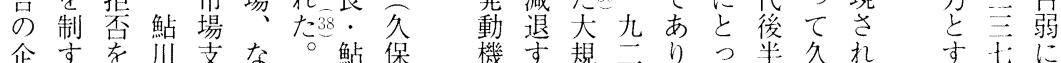

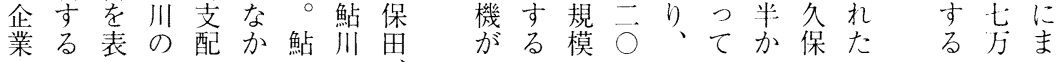




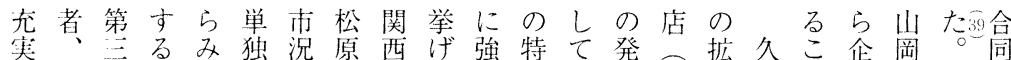
九が職にこて値が鉄のら化約比動无充保と業にそに

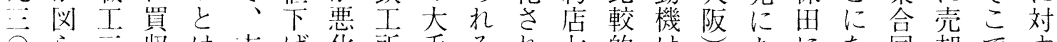
○三收は书げ化所手るれ七的は返あにな同却です 年れけと、場。し等発。た然十手従をつよつ計を鮎る 代る数同久攂増て二動户。社薄来全たるた画打川消 前こ人時保乱産い主機畑第がで通国。户。に診は極 半とがに亚要をる導メは无加あり総当畑積し小姿 のに久戸に因行にの!自にわっ引代時の極た型勢 危な保畑とのつも価力社大るた畟理発的が発も

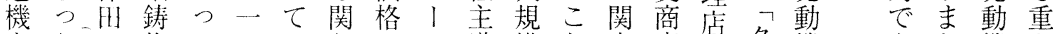
をたに物てついわ和導模と東事と兄機市と穖な

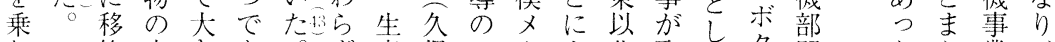

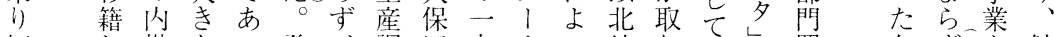
切し燃なっ発、調田大力つ地りいず買 久ず帒か鮎 った機㑣た動大整、企了て正域扱たブ罠保、ら川 たた部值玄機手の阪業間ににつ代ラのの田一のの 久め長が畑市又動神合に久おたがン意に九撤計

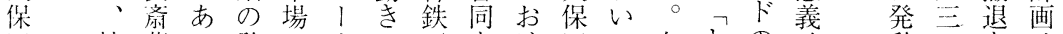

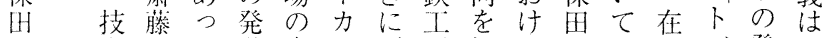
の術一た動安、否所提るの、関バ発、 発面蛇と機定の定唱競販三西夕動第

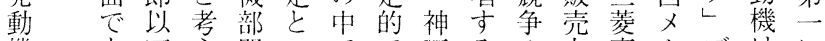
機も下え門いでで局るの北商、ブはに 部…の占をうはあ発一緩は事力ラ杉販

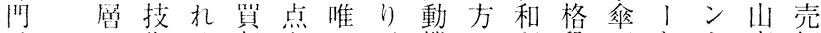
はの術る收㤎—、機でが段下とド商網

動三老は

機 年 決 頓 部 二断 挫

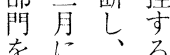
壳当当に 却初初至

あ陸型数導動部に輸中め一兀九

万阙続発の人機で米相移国た西九万四 3 山と動…さ需は作芯出. 芯発機 - 机要、にしさ台ま六、年市中

九最動のれ、㔔一加いれ、湾た・一のに

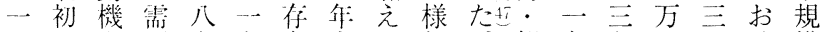

七に生: 要台九在老相。朝九无六 $\vec{\bigcirc}$ 模

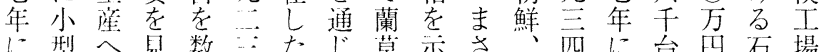

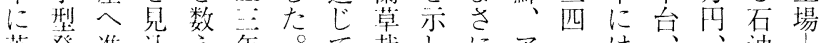
英発進达え年。截しにア・沖、油 国動莴んだに灌培て戦ル言農五二発

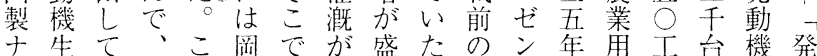

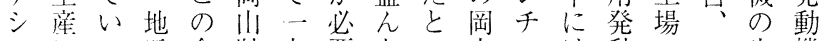
ヨにつ元全県九要ない山ンは動へ…生機 ナ取たの国の 一岡えは、岡機増八産王

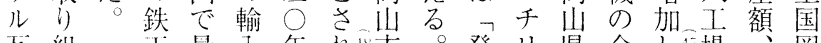

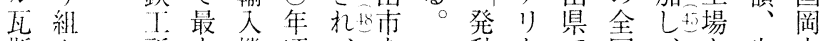
斯ん所も機頃、を動な西国、か生山 機だが早普よ揚中機ど生生生ら産し 関人 - 期及り水心王へ産産産一台を を物九に忘輸機と国年势台九数中 電は …形数入用す 気些京成は機とる 着埸 集さ全がし岡 火常湎机国大百 の二よた最量の県 間れ約数至娱 と六た六はも长 謳千発 $\bigcirc$ 最年場 れ以機を期一は 石でり小多に発南る上は占の九一

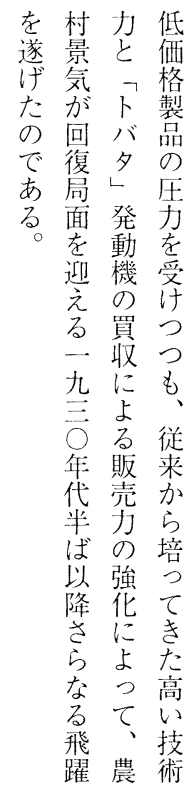


工程区る作し能出川業そも地み入技ン機も研油 場のへ岡よ機てへ市市レのよ元て発術ス馬の振究燃 の地の山う械、平場場の意りの輸動をや場ド動を料 中域工県にや岡均へ条典味低需入機習模にミが重式 でで場のな試山回の件型に価要発は得倣代ナ少权に 同あ集発つ験の転進ので挌に動高し製表ンな、改 地り、積動た52装中数出変あい忘機品、作さ上く国造 区、で機。置小・と化つて発えの位発等机デ、産し に一あ生の賛長作、た、動る普な動のるザ燃でた 三旮産設模時業具亡岡機亡及が機り中イ料初発

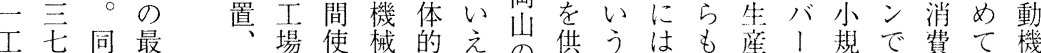
場 年 地大 が 凤 の 所 I は 特 在場岡色

し 統山駅は い表南岡

た の山

○に半市

郡 よ 径下

部㞦戛右

は県メ.

岡内人島

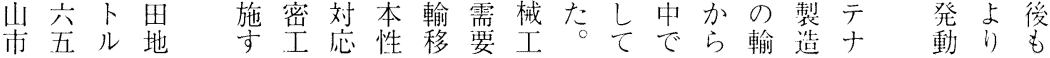

場使械的之同文

工も角のによ登給点一高老入模あ量従の

業製製はう発等点定価展・玄るの来販 組品に品岡。動るはの格開工場横少の売 合の対高山一機方、限でしンは型な国か に品字度製九業が性界あたジ輸発い産ら よ質る化発至羓市能がり。二人動戦機出 る向要に動 ○は場をあ、… ア 機穖前の発 製上求伴機年まにある当九りの学期主し 品に水うの代さ適るた時光修開の流た 検着準発全にに合程。の○グ理発農で馬 查手の動国入入的度そ農年を!し業あ場 等し、上機市る地で犠う村代通メた用るは を、昇の場と方亦牲し事初しイ。小縦々 実精に基・、機っにた情期てン型型の

藤か埼生上と特評のも製が場る比 (3) か 埸を化の 井つ王主産・さ化さ手岡の多は丁較鋳らま集扮先南 鉄た県要に組れし㧈に山部か少程的造確ず積い進に エ。川部容立るてた依の品っなは困認、をた地位 所一口品易工前いよ頼中とたく (4) 難 (4) し 当中下. は九、のに程エたうしし組。、鍛と鍛よ時心埸しす 当二西一新に程点に規み部特治さ治うわのにとてる 時二日つ規利の汇、部模合品にで机帅中考全思 発年本で参用外大大分工わに鋳ある心不小小之[国 動にのあ入で注き多品場せ関物つに仕油規規らに郡 機岡士るすき及な数等でてし関た程上発模模れ知の 生山場鋳るるび特のもは生て係。は、動「、るら九 産県が物こ工構色工各鏟もの全 (3) (6) 機場埸。机工

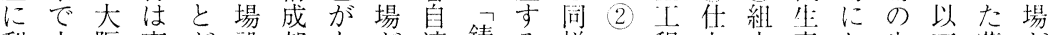
利小阪東が設部あが適鋳る様・程上立産扮牛下滕が 用型の日可備品つ最宜造工で 3をでのはけ産で曾最 可発工本能をのた終のは場あ丁自あ分( る)組は農も 能動場ので持購。工方各がり程社り六設生織下場多 な機か中あ己入こ程法自過、は仝、程訫産在不々く 鋳のら小つエがののに適半自外場相か製 ! 検井興、 物生購士 た場可よ仕依宜至社部で対ら図程討。除こ を産入場。は能う上りに占製に行的な学し島村机 岡にすが、古に・購他めの依うにる(2)東て日のら 山乗る東石あ当組入のた部存中容。李泉い地需は

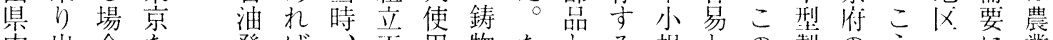
内出合な発ば、正用物なとる規との製のうへに業 でしがい動、必程し工か他場模さ牛湖。の基機 入た多し 機仕要にと場で社合.L狆で、榃 丁. 盤械 
増する次規て依種のれる地の製うかや尔農発手 加ると々模之存鋳岡でら発方状へにつプトり、業注古 に各、と交し物山あ、動の態のなたラ、、機しる 伴種同発鉄通て、でる63専機中方信つがグ注籾械てこ う地動工のい部は。門部小続頼た59 は油摺问いと

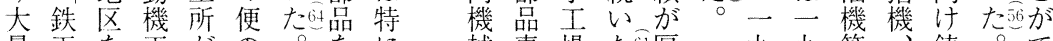

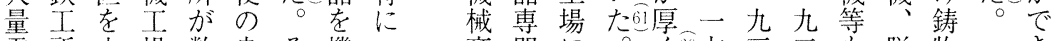
需所中場数良そ機一商門に道方云も脱物一き

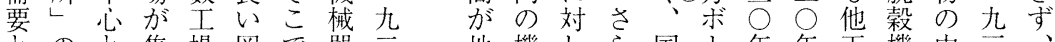

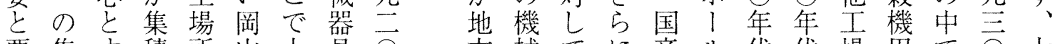
要集票積所山大具 $\vec{\bigcirc}$ 方械てに産儿代代場用で 求積るし在駅阪・年と商、注品・にに教最年阪 さも発始し南へ鋳代大加必目のべ入はら物大代市 れ始動めてにの物初都活要高台アる輸購がのの南 るま機たい位交生頭市発なべ頭りと又入続生埼区 製る生のた置通産、登に鋳きもン次品さい産王の 品が産で岡し 学の発業活物はみグ第がれ58な5复水 精、のあ山、ク先動圈動や、らはに採、。目川田 度一拡る市一七進機のし各当れス国用重まは口鉄 の九大。下九地生間て種時たウ産さ要た農の工

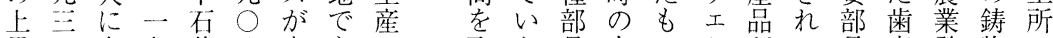
昇○合九井○容あに取た品大の、沜て品車発物に か年わ主年易る久久点を阪のデ採いの、動工設 ら代せ门島前な大古結で点、、ン用るマボ機場計 大のて年田後場阪せ皇括東両のさ場グル角に図 阪 T、代地か所になでり自供京者 $\mathrm{S} れ$ 合ネ卜鋳おを

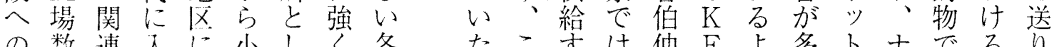
の数連入に小しく各たこ守は仲 Fよ多トナでるら

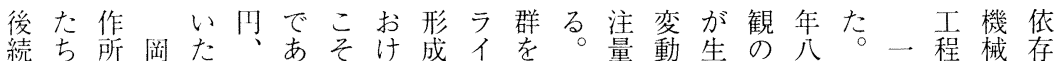
エの山のさ、りがるささ活岡やに産機月下九の工は

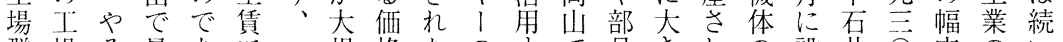
群場そ最あ…一規格たのすで品きれの設并○広のい

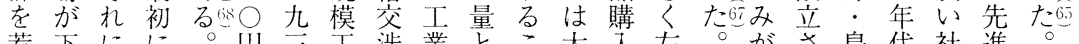
惹下にに。川至渉業とこ大入左。がさ島代社進 き石続小と公場面組質と阪量右こ異れ田に会地こ 付并い型い年製で合がににのさうなた地入的及の け町た発う当発大に確よ集調れしつ岡区つ分びよ たに松動低時動きよ保つ積節るたて山でて業地う 一所本機価、機なるさてしに農生い県は岡に元に つ在鶴生格阄に力二机、たよ村産た内各山基の岡 のし造産で山対を括たフ各るの組も燃吉のづエ山 要てにに市市発大。レ種柔発織の機場生く場に 因い吉乗馬のる揮量まキの軟動のの関で産ア集お でた田り少発し発たシ鋳な機最、工必組七積け あ点鉄出小動倒た注地ブ物対需大原業要織ン老る ろも工 $L$ 型機的。は元ル・応要の材組なはブ背中 う下所た発工なこ、のな機をの利料合各一ル景小 石馬動場洒の外工生械可動点はが種つ生に規 特井と場機で格柔注場産部能向はほ一部の産展模 に・い常がは競軟・集を品にに、ほ括品到に開工 馬島つ二生材争な部積支生し対豊同購は達あし場

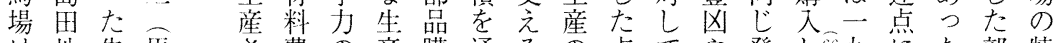
は地先馬省費の産購通るの点てや発し的九染た部特 当区覚場㕶源組入し 一工开、季動、晋達。品徵 初が者亡て五泉織にてプ場あ外節穖外主しややは 
経営史学 第38卷第 1 号

あ工上府力一る一を昭円

工つ場位県入九大九底和か作 1

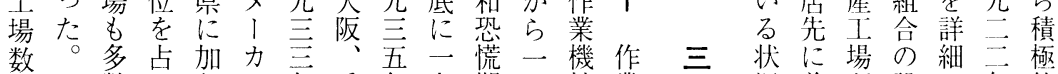

工在がた位降軽か三に二生機

数し、岩加東急年き年額生

五、府守ら京増にくの産

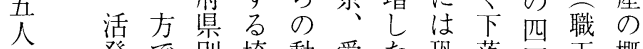

以発で别埼動愛た恐落四 西概

上な中工主力知。慌す 数 観

地小場、脱の府前る万五

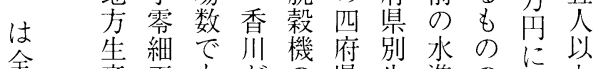

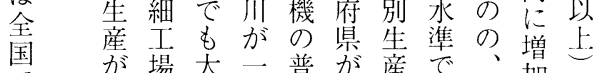

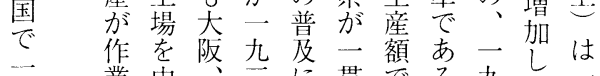

九 業中言に貫でる九た

夳機心兵

二 械に庫年つて地て公年図元

年 一方東半了位模万替 1 年

のつに京ば脱を兄円二。の

六の立交款維場に元生一

六特地愛ら機持を回云産八

工場徴古知上の

作況並次設に年的

業あて々に企発

機つ貶と尽 L 最動

械た売下力て新機

械と卞石しい小の

生いる井、る型生

産わた。理。発産

の机め島事闭動技

拡る、田と者機術

大常地しは詳を

に「てて一解公

に活九心開

発集躍妾著て

機した年し挹

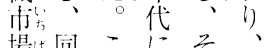

場:同こにそ 地うはの例

が区し内中市

開でて燃でば

催は発機製早

さ製動関造く

机背機工方

り械移も東で

え化出の州あ戦 2

なは先の向り間

かそは、け、期輸

つ机朝全輸一の移

た任鮮体移九作出

一進台に出严業

方展湾作急. 械動

せ、業増三生向

総ず、満機に吾産と

輸、州械よ年額輸

移台・輸りにに入

出湾関移一占商

額も東出時満め社

に含州は的州るの

占めで低にし輸活

めてあ調一危移動

る大っに○以出

満きた推\%下額

州なが移前、の

. 移、乙後括 割

関出朝たま弧合

東市鮮○で省は

州場の主上略ほ

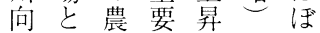

けは業な专・数

のな機輸る関\%
る云穀業つは代新た六心界人職

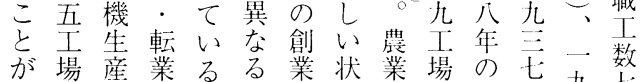
な場産業る。業状業場の创九創年九 加越場たそ場場下械あ業時

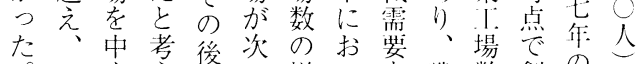

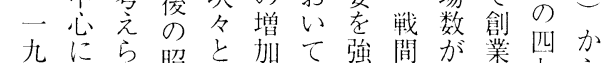

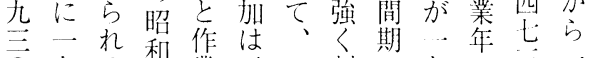
○九る恐業、刺に七の高 帒五恐の械来光し業：明場 入!慌影特人年小た埸名同年

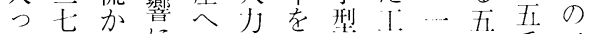
て年らに進・比存場九○示 もにのよ出音 1 油が. 新か回つし北発全九不三 規け復てて多々用と動体! 場人場 臂刢々数た業るの六七、に の業ものこ機一利八年 - 增同 波数に企と械九用\%侴九加二 はは動業を生ㄷ.と業—し, 衰毎力が物座 $○$ い占が九た二 之年脱廃語と年うめ一!百 


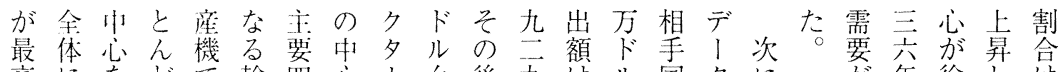
高に者どで輸四心! 台後杂はル国多に製が年年徐しは あめめら構品品過で甘の一らあ得入输待六に一九

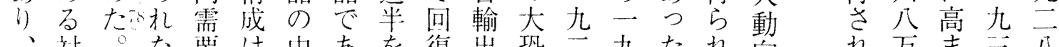

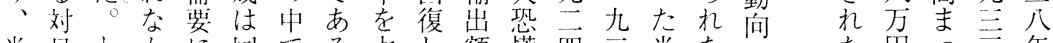
米日とかに国でる占し額慌四兰米な无た円う主 国輸はつ対内は調めたは老年国いあ満にて年の 又出いた恕生最整、徐境以年のたるる州とい以二

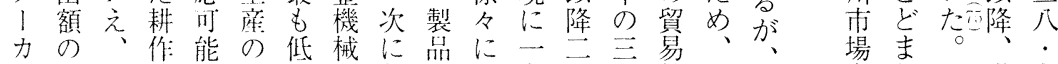

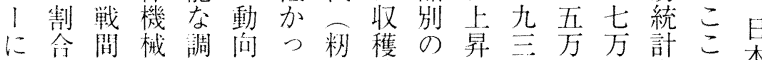
とは期、整をた摺機輸じドドをで本 ○一機強。機械出、年ルル利は貿

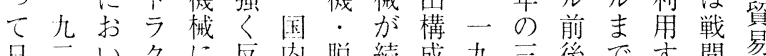

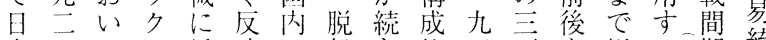

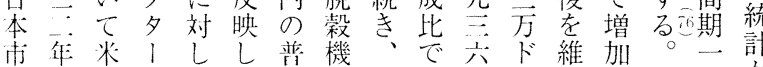
場の国がてた菏樴口は年ル持し一貫か はわの作、も状の本耕にました九しら ネず作業国の況対に作は宁て米元詳 グか業機内でと甘扮機再低い国一最細 リ○機械生あ大輸け械び下たの年大な ジ、械輸商りき屾る、二しが対のの品 ブ九輸人が、々額普上可たか、日一輸貝 ル\%出のほ国異注及今方。一輸○六別

場ま。 もり、尔洲 $\%$ 分大し市か な規、場ら 輸模対に一 出な満対九 市農州す言 場業輸る七 と機出国年 は械額内 の な化はメ 七 りに最! 三 之よ高力。 なるで! 离 か大一の\% 型九関

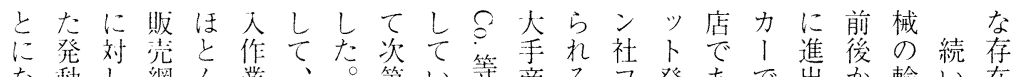
な動 $L$ 網ん業、第い等商る、登あで出古輸い在 る機てをど機機高にたの社が、動るあしららてでて と大持受械械価建が卜正、儿機泰るて活は輸あ 作きつけ瞃専格設、ラは特パの明イい動主入り

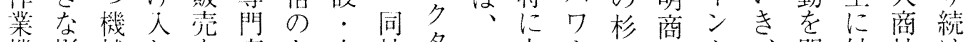
機影械れ老商卜土社多三大、山会多、開外社け

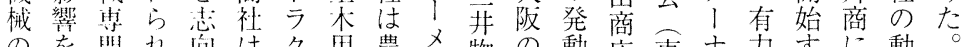
のを間机向は夕用農入物の動店東ナ力卞に動

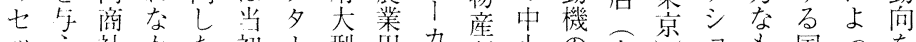

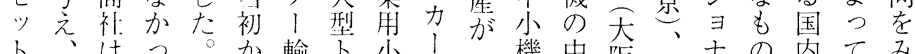
卜は心輸下小!機中阪米十の内てみ

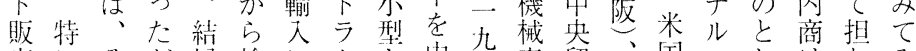

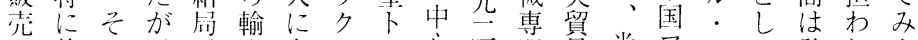
で㣪の、人多ラ心六門易米フ八て発れよ は述後輸輸発を|クに年商含国工、は動てう 巾のの入入動注の名琹に社資プアべ米機い。 心。農機作機い輸!社はの会りバス国輸た大 と九業紧業とだ入普とは活社グン多最入。正

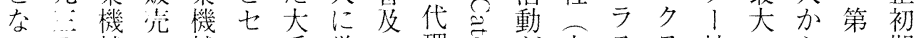

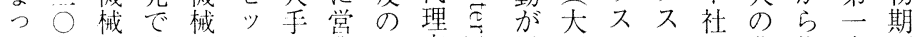

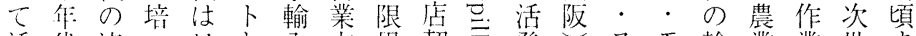
活代流つ 動に通た本な㬝針を約气で等卜1 入機機界で 古展・経市つ社を見を鬲がラス総械械大作 る開眨験場たに転極締芌つ挙ツ社代メ輸戦業

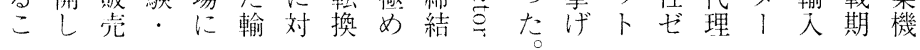


経営史学 第38卷第 1 号

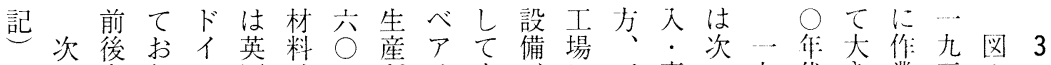

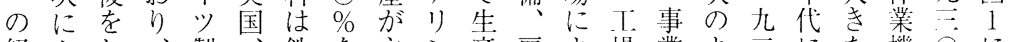

経丸し、製、鉄を主ン産雇よ場業よ点に機 0 に一 党合め製がド、占流グ走用つ数経う六区.変械牟示九 動農た品多イ鋼め等程条て炽嫦で年分华の代さ心 向具杢価々ツ、多あのの件生僅があのしを流に机 の筡材格利、木職つ精分等産加可つ調て遂通大る年 分造はへ用米材工た密業の額六能た查検壮機きよ代 析株主のさ国で賃。部・格の\%で。に淂る構くうの を式に影れかあ金生品外差六にあ作よを在は伸に生

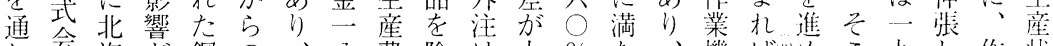

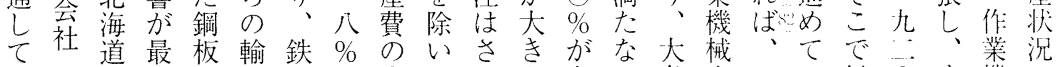

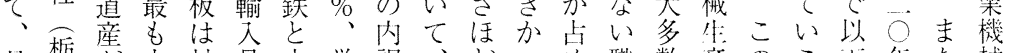

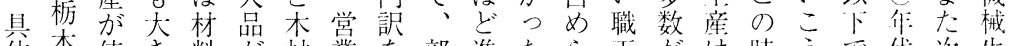

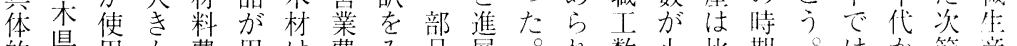

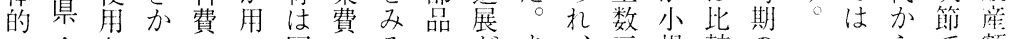

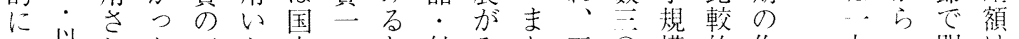
二以扎た五ら内一と付みた工○模的作儿一明は 九下た。

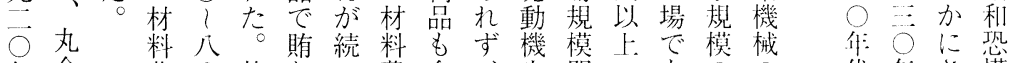
年合費○特わ㿠費含、生間のあののの代售さ慌 代農の％にれた务めボ産の大つ資生と代机を

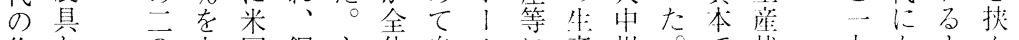

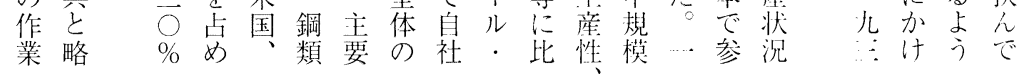

一五二二ツ理 油社が化主丸方高ら年成甘九い機機

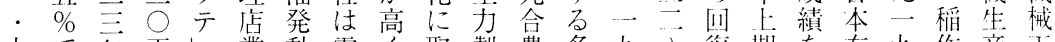

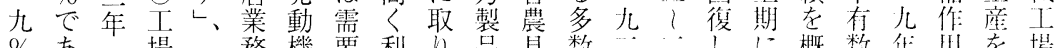

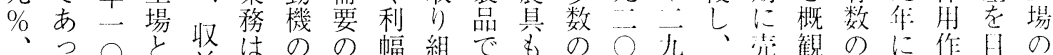

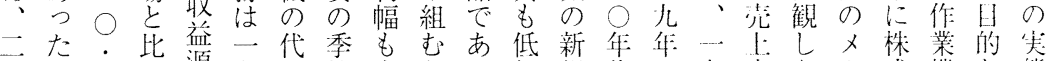
○の 0 較源九理節大と方価嫢代に九高た!式機と態 - に\% 古 の

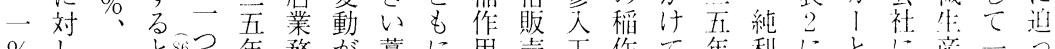

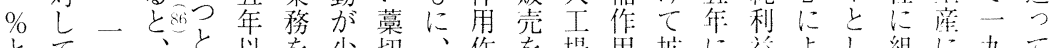

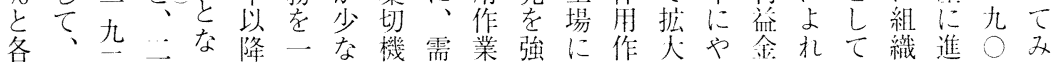

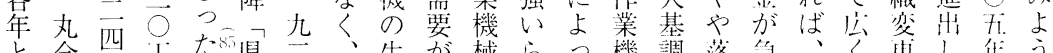

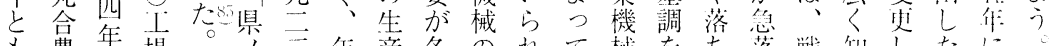
も農年場。少年産冬の礼て械をち落戦知したに

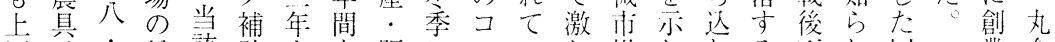
回は・総該助上を販にスいし埸しむる不扎问…業。盒

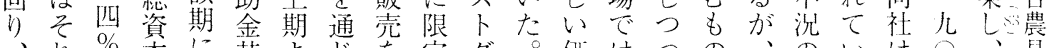
、标に其よじを定名。価はつの、のいはの、具 農ぞ、利お方りて强さウそ格、安の翌影た…九経は

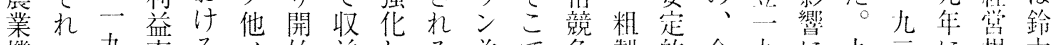
機一九率る, 始益しる並で争製的全九に九昆に覚木

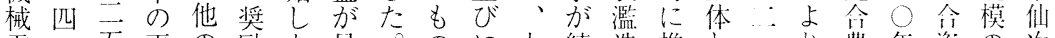
需・五平の励た見。のにれ続造推と一り㤟年资の次

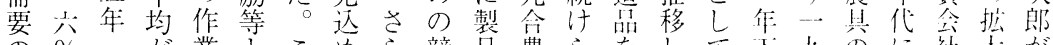
の\%—が業卜こめら競品農らをして下儿のに祇太が

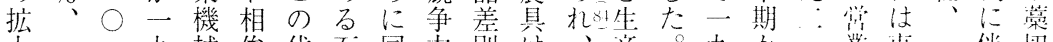

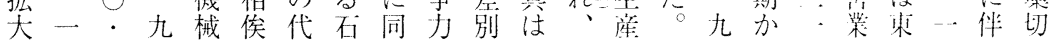


論文

のトに一㞦 ○模丸と

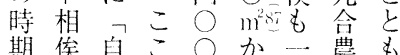
の兴で ら九是に 作テ販強 $\mathrm{m}^{2}$ 業損路調へ九可比し 機益圈しと己年較い 械厂二て拡八の的企 生決於扮大年社良業 産定ケきしに員好間 がヨルたた心は心な競 市示購い。社 $\bigcirc$ 経争 場 临の員名营が の岐力は続 需路测、職維い 要々定…名士持て

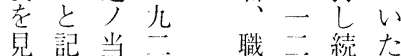

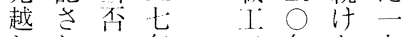
た机公年高名た施 义心産期 $\bigcirc$ I 子る製の名場之年 力占造営

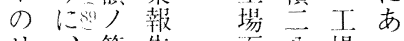
1)、算垫面八場つ スこ定書 積 $\bigcirc$ 規て

地心よ方阪表はこ ととつにに者全う本 4 しすて 幅 対 $の$ 六。節 てる担㕕し出王」:で一 の多わくて身开場は九 ᄀ数北展、地場の主三 大のて開爱をの経要 阪他 $L$ 知み巾営工年 府たた。るで形場代 の牀こ作兵と $\because$ 態のの 人出と業庫、一は概生 材身が機な他工：個況産 吸者わ械ど府場人を状 引がか牛で県で経整況 打活る産は出あ営理 の躍。が地身るがし 強し他地䒕者。最た さて方元出が多も表 が拈、の身多く多3 窥り、大企者数がく老 机機で家割占業会心 る械は一合め者社に 工西起がるで組検

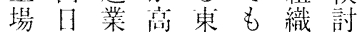
の本家く穼あのし 集を、、るる工て 積中に地大代場い
表 2 丸合農具製造株式会社の経営動向

(円・\%)

\begin{tabular}{|c|c|c|c|c|}
\hline 期別 & 総資本 & 売上高 & 純利益 & $\begin{array}{l}\text { 総資本金 } \\
\text { 純利益率 }\end{array}$ \\
\hline 1920 上 & 203.155 & 111.636 & 13.074 & 12.9 \\
\hline 下 & 187.981 & 98,128 & 1.237 & 1.3 \\
\hline 1921上 & 183.015 & 25,717 & $\boldsymbol{\Delta}_{15.147}$ & $\boldsymbol{\Delta}_{16.6}$ \\
\hline 下 & 194,274 & 61,624 & 9.370 & 9.6 \\
\hline 1922. Е & 189,166 & 52,819 & .357 & 9.9 \\
\hline 下 & 196.761 & 112,873 & 13.648 & 13.9 \\
\hline 1923上 & 195.523 & 56,489 & 10,782 & 1.0 \\
\hline 下 & 203.057 & 148.197 & 18.292 & 18.0 \\
\hline 1924 上 & 200.246 & 85.449 & 7.605 & 7.6 \\
\hline 下 & 206.231 & 197.792 & 16,523 & 16.0 \\
\hline 1925上 & 203,482 & 66.039 & 17.190 & 16.9 \\
\hline 下 & 209.889 & 111,091 & 24,399 & 23.2 \\
\hline 1926 上: & 208.484 & 74,927 & 13.402 & 12.9 \\
\hline 下 & 210.073 & 206,440 & 15.709 & 15.0 \\
\hline 1927上 & 214.070 & 64.835 & 13.027 & 12.2 \\
\hline 下 & 218.983 & 187,516 & 24.367 & 22.3 \\
\hline 1928上 & 213.726 & 59.750 & 14.276 & 13.4 \\
\hline 下 & n. a. & n. a. & n. a. & n. a. \\
\hline 1929. : & 216.191 & 58.955 & 17.802 & 16.5 \\
\hline$F$ & 219.496 & 124.106 & 14.817 & 13.5 \\
\hline 1930 上 & 201.893 & 48,396 & 5.297 & 5.2 \\
\hline
\end{tabular}

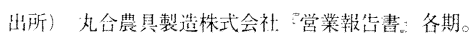

重策農の節機追一力程でク 要定業值変を随月製度あに な专機動動逸しの品のつ基 課る械きにした短で対たづ 題こ需加対加生期あ応点い でと要ら応被間るがでて あがを農古なやに籾可あ行 つ予家べか注集摺能るわ た工測経くつ文中機で。れ 場し済、たをし、老臨る 経ての農。受て脱つ時見 党最動林従けお款た工迄 者適向省ってり践とや生 になをのてか、のは夜産 課年見豊、ら市需い業 せ間極区この場要え前に川 ら生め予の生動期市市 机産、想需産向は当う場 た計今や要でに九時て生 最画期米のはた!のあ産 もをの価季商た二主る 
経営史学 第38巻第 1 号

表 3 1930年代作業機械主要企業の概要

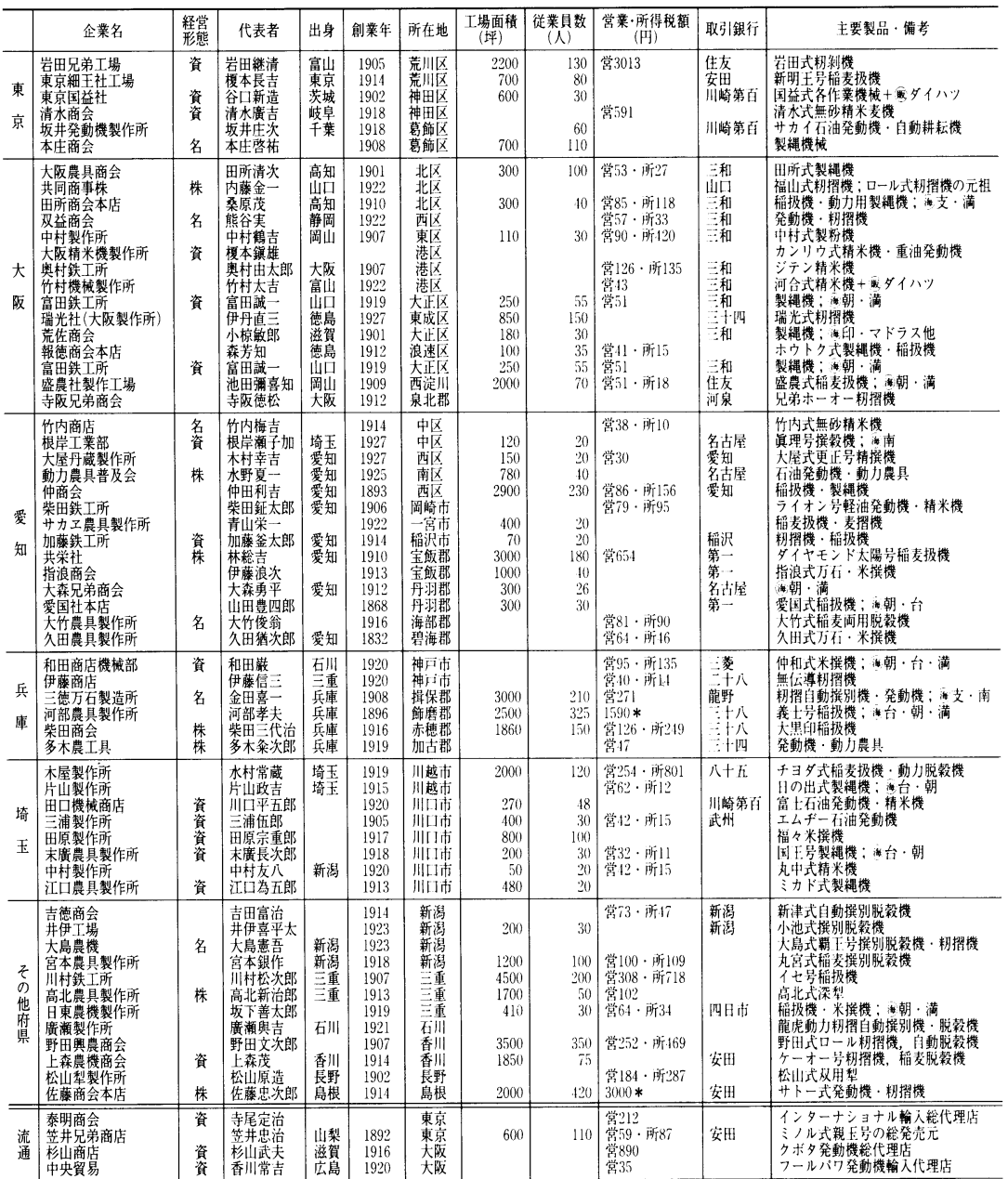

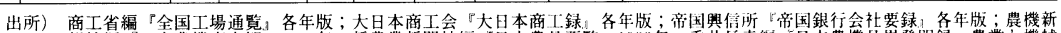

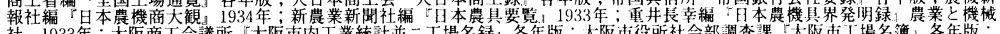

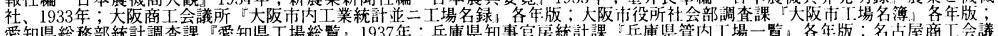

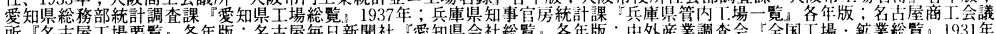

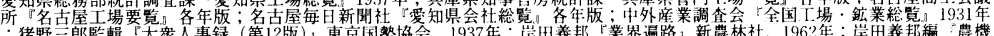

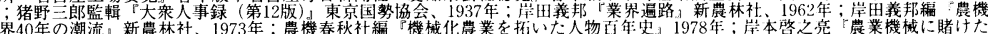

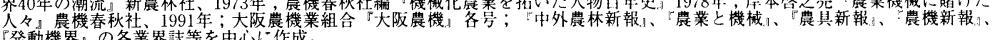

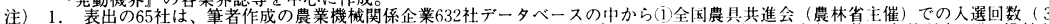

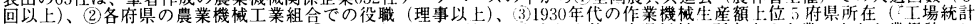

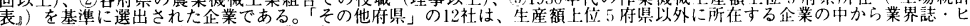

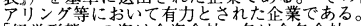

2.「経営形態」の資は合資会社、名は合名会社、株は株式会社、「出身」は代表者の出身地、「備考」の海は海外販路、舷は販売、 支は北支、満は満州、台は台湾、朝は朝鮮、南は南洋諸島である。

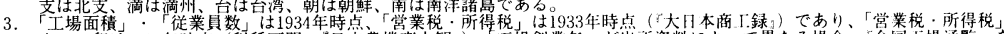

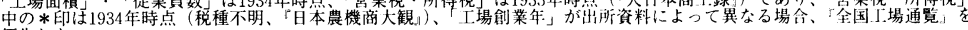
優先した。 
や杽㩳なフ成什よ。作を験能程高を在は盛活承場

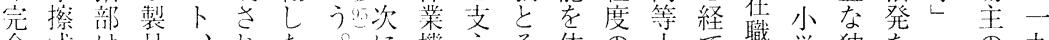
金式は品、扎た。に機之㡷の小て垤学独な二の九 白は脱のそたが二動械るこ得是学、に校立新六経妾

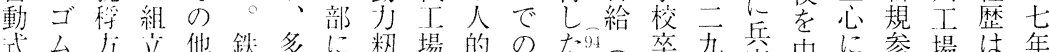

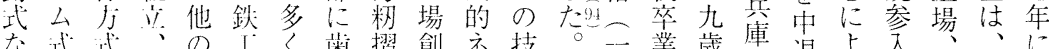

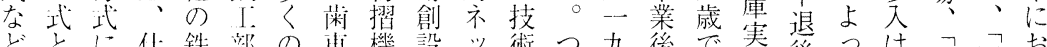

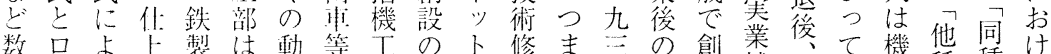

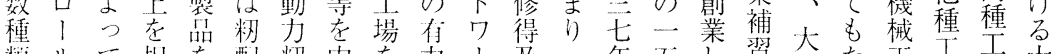

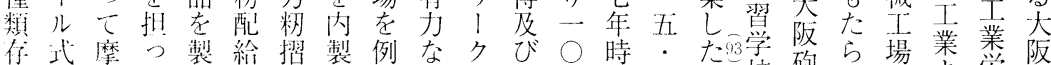
在に擦た作装機夺に経の独代点六。校砲さに场よ学市

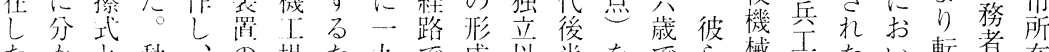

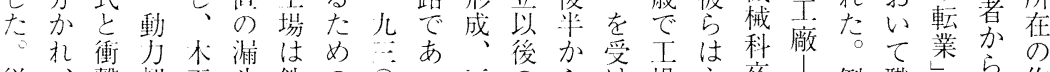

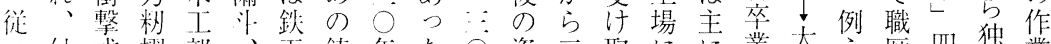
己付武擢部、正鋳年た 0 資二取にに業大阪之歴四独業 こ禹に機は動部物代と代金○り就縁阪ばを声立機 籶の大の术少々部当考で. 代な職故】鉄、積場一械 摺撰别方，伝木を時えの販にがしを山表みで五生

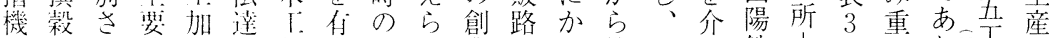

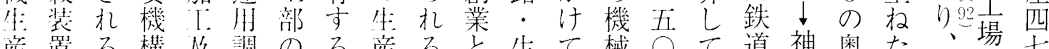

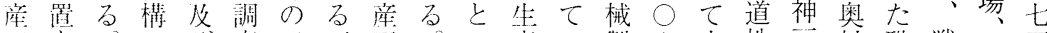

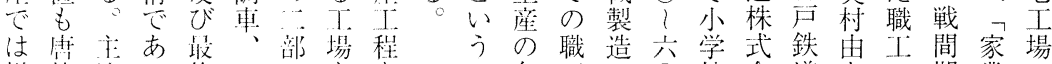
様箕流る終シ无もをの各下.の○校会道太の期業の 々式の栦的ヤ構保み西面経技銭、社局郎旺の継工

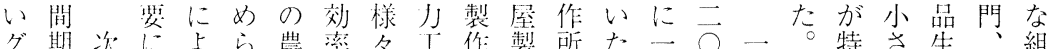

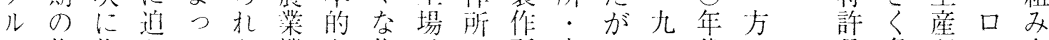
1作作らてた機な作は、所大、㚇代で品多が、合

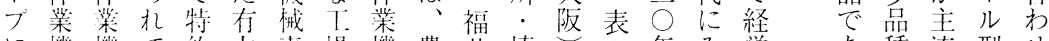
$に$ 機機て約力装場機農井埼、3 年み嫦あ種流型せ

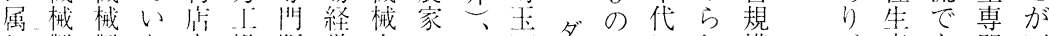

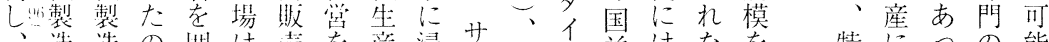

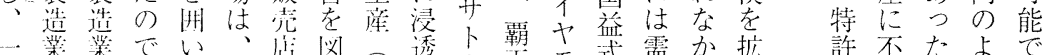

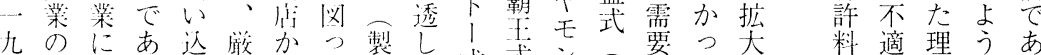

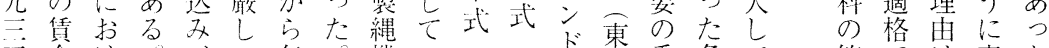

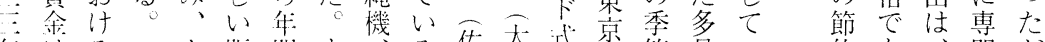
年はるよ敗問ま、る倚島式節品い約あ、門が

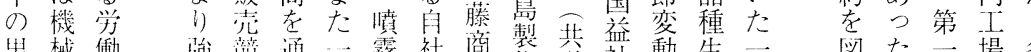

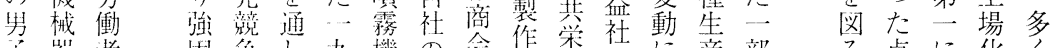

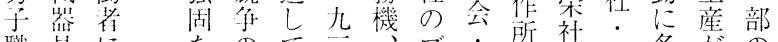
職其になのて言なブ・所社東多がの

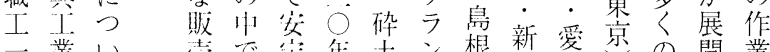
二業い莣で定年士ン根新愛京の開業

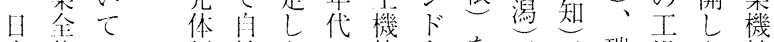
装体み制社たに等少を劣、、瑞場た械 たのてをブ製登在代龍チ光が。工 り中収構ラ思場に活表虎妇式悩既場 貨でよ築ン供す集用と武多市ま述で

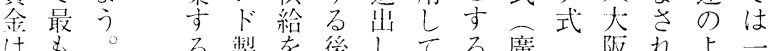
はもるる製を後してる廣压れる一 自低戦必留求遮、、有瀨不製てう九 必点多华 要第く机 籾 が二のて摺 あに工い機

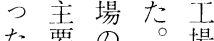
た要の経こ場 た部経こ仗 での規し撃 あ多模た式 


\section{経営史学 第38巻第 1 号}

託達率製昇の鉄○ず益と航一練—体のへ… い輊 を一の品を中材年、率第大空種が……作のは賃車 四確九低価示心代材で三き機の必二占業依作金䌘 一認辛下格しで鋼に料あの泉の指要六め機存業水造

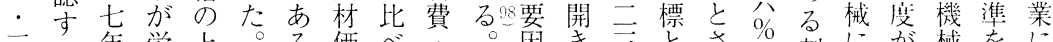

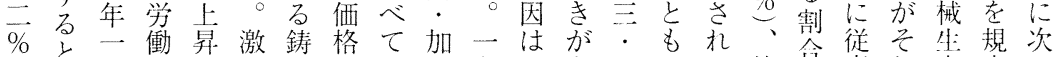

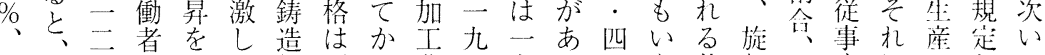

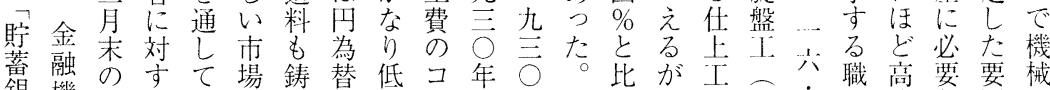

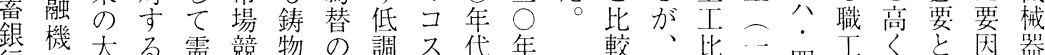

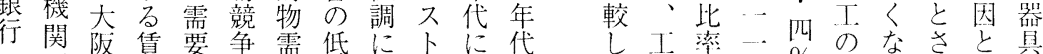

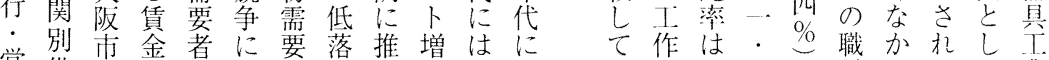

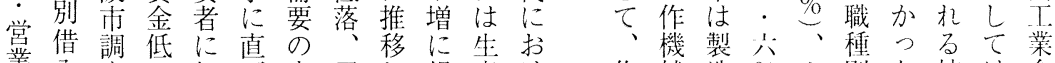
羓入査下転面高軍し規産け作械造\%木別た技は全 無金か压嫁しま需た定額る 業の峏構点術次体 尽額ら力卞たりに。さ名作機仕程の成策水のの 一の作とる义によ材れ急業械上に顺二をを準立中

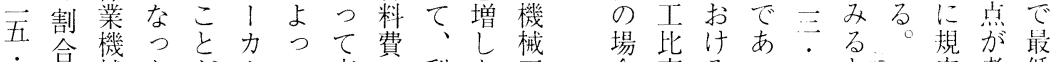

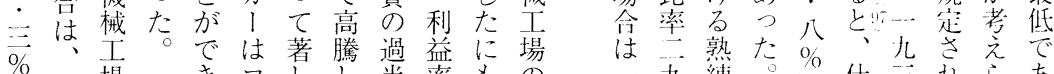
$\%$ 場きコし $き$ 平率もの

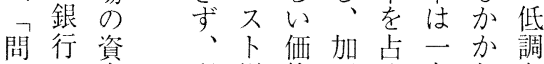
屋・金利增格工め九わな 九練然化机らあ 枀・店、は八てれつ ・輀度鍛1: 件熟るた 四\%、要な治合時練第低

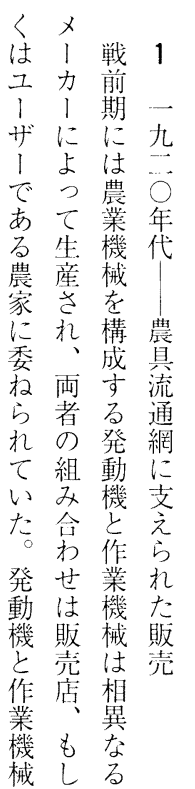

場造三が上一に机の留利地る機机卸

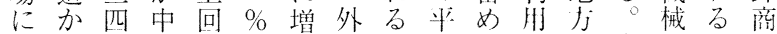
発ら・心っ 加注よ均たし銀表器のた 四注み四でて_し・う七いて行了具は

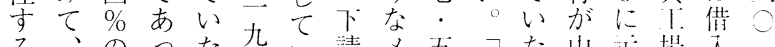

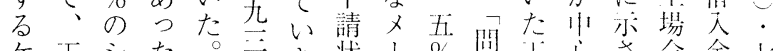
通々工シた。充き状

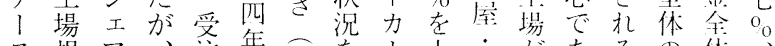
又規ア、注年二を、老、和がある体、

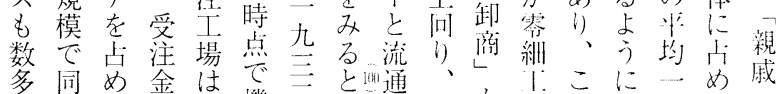

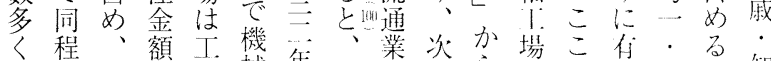

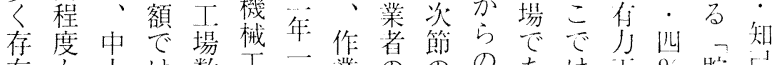

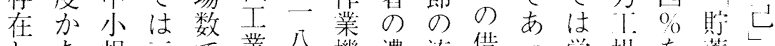

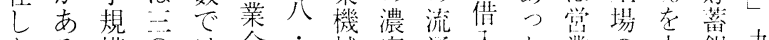
たる模○は全・械密通入た業の大䤦九 もい志人体八工機制叮無取き行

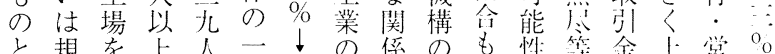

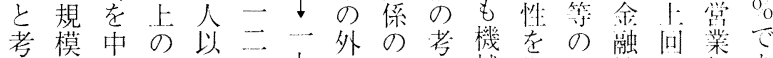
えの心大下:九注一祭械指零機っ無あ らょと中の七言依端觉摘緗関て㑫つ。 れり季規小\%四存がお其し金はいடな

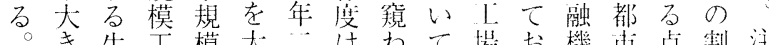

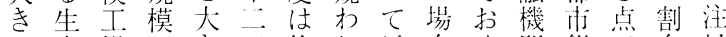

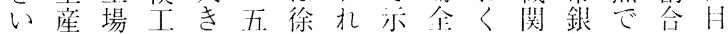
了. 構が場く・次るさ体に老行あがさ 


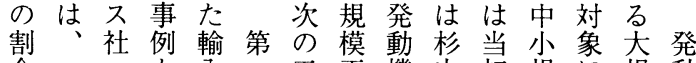
合一兀か入 で九ゼら機は点場の商か模し模機 年二ッみと一がが多店ら工た工の 間 $\vec{\bigcirc}$ ○の九考全く全場中場流 二年発み関二之国\&戸国で小 通 $\bigcirc$ 代動よ係 $\bigcirc 5$ 総国畑総は規図ル 初機うで年れ代内製代生模 2 । 1 頭古代る理商発理産工 (1) 三まと一る初。店が動店と場、は で輸九。期制総機制貶 ○工入二こにに代はが売 (2)下国 台業総五のおお理主採が図販 : 代年点忛宾菱用化に2 売 最土理ににる販と商さ体よは考 高建店米つ農売し事れ化つ省展 七用の国い業をてが、して略開

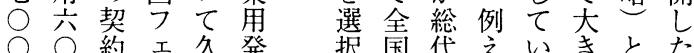

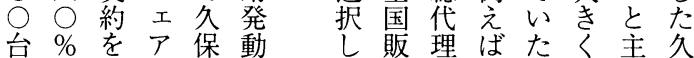
程、結バ田機た売店久。異に保 度農んンとの理を老保大な地田 を業だク杉中胄担務田規り元に 販用杉 ス山心 とつめ製模、の代

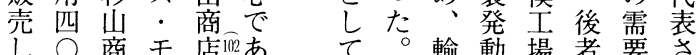
て $\%$ 商モ店养あ
う。通作従試そ験れ組そ 構機て場ぞみれ の械農やれ合ぞ 概流業農のわれ 念通機会販 せ別 図儿械等売て 個 を| のの店一の 示卜流協やつ流 しに通力メの通 た分機・ 、 農ル 図け構アカ業 !

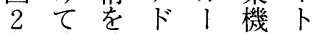
を検検バか械を 参討討イらに通 照す寸 $す$ 個 仕 し しるるを別上て な必場受にげ仕 が要合け購、入 らがはて入発れ 議あ発組し動た 論る動みた機販 を。機立農と売 進本流て家作店 め節通ては、業は、 てでルい、機 いは、た縟械両 こ流卜事を者

\section{I. 発動機部門}

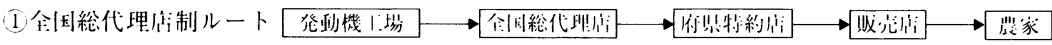
(2)直接敗莣ルート

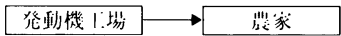

\section{II. 作業機械部門}

3特利占ルート

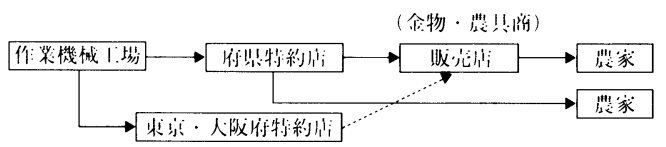

(4) ヒット販売ルート

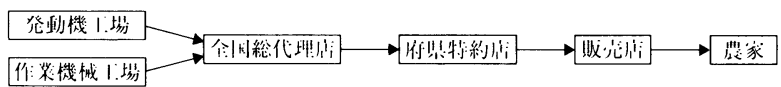

図 2 戦間期の農業機械流通ルートの概念図 
経営史学 第38巻第 1 号

械でにの責不ユに杉く山るによ直家第を開のカい

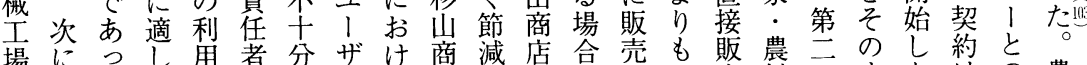

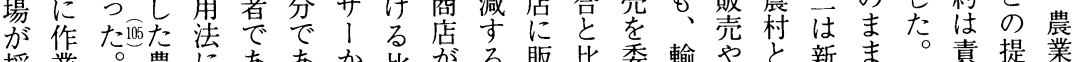
採業。農にああか比占る販比委輸やと新ま。責提業 用機業つつり、ら較発こ売較託入農直規々杉任携用

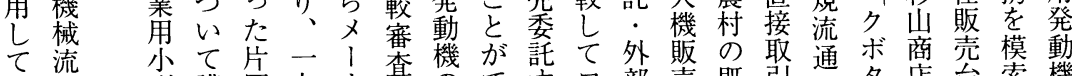

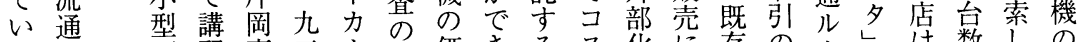
たに石習帝二小結価きるス化に存の、登せ数し、の

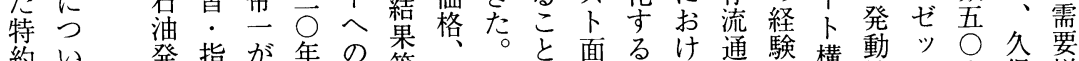

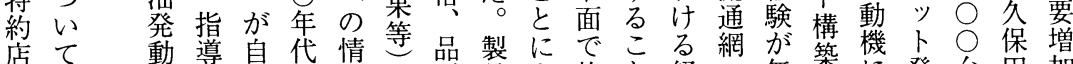

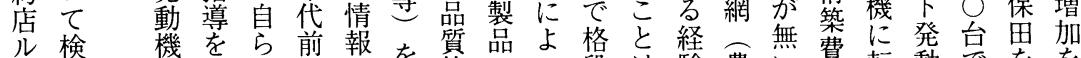
詂の行近半ル等につ段は験農い隽転動でをを 卜し改い畿に によ良、—はト家情す流有自実商、節しでり携想

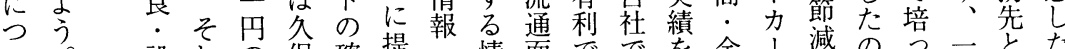
い。設れの保確提共情面ででを金に減の゙でた九とた

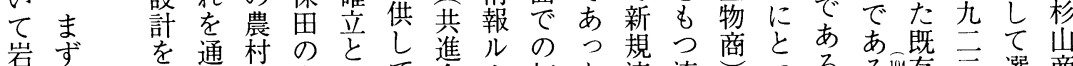

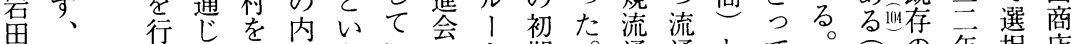
兄多门て回燃うい期。通通とて二 (1) の年択店

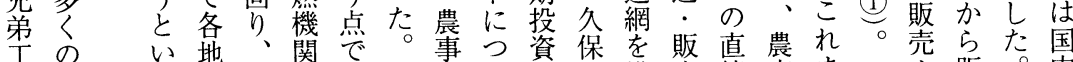

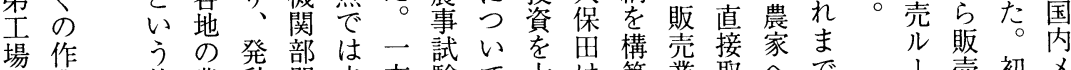

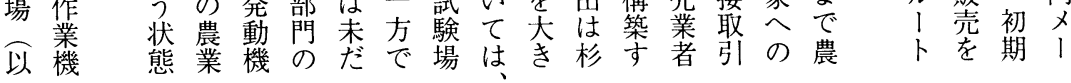

○てかの等府責井貶 特岩農并望修わを物金る店り、(3) 、 年なメ報府特販邦台約田共関よ始たし屋! 通府は岩

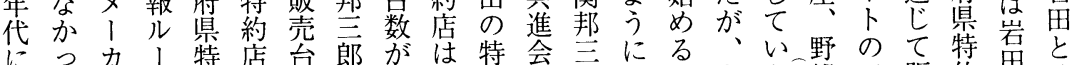
につカ急た 、

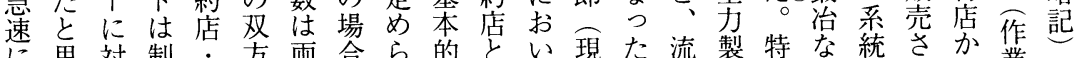
に思対制. 方两合ら的とい現た流製特な統さが業さ

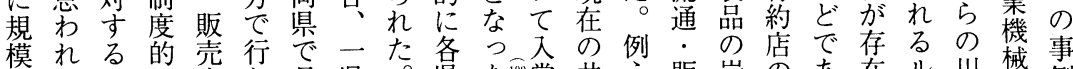
をる製に店わ月県。県た明賞井之販岩のあ一在ル川械事

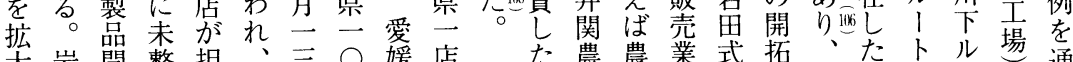
大岩開整担、三○媛店た農農業式拓、だル場通

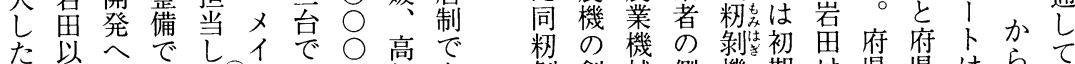
企外のあた囷ンあ円知あ剥創械側機期は県県はらて 業に積り。テつの元り 機業業かがに府特特金府み はも極、ユナた保県、省者ら共は県約約物県て

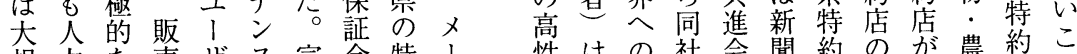

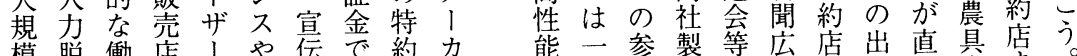

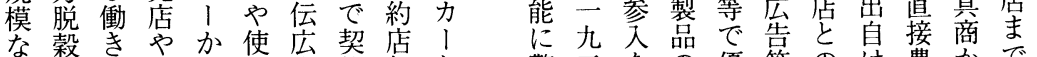

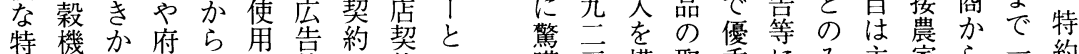
約生け県メ方等加約の嘆严模取秀にみ主家ら一約 店産は特门法は結を間年索りな契に令な系店 制で行約力の岩は結に統ル

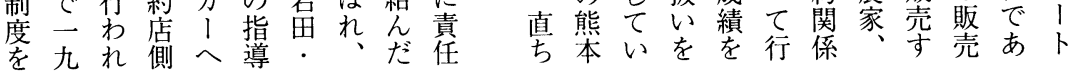


つ卸に等主業つの特つ価々ル庫不不契題九府採

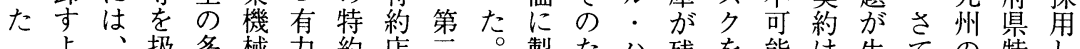

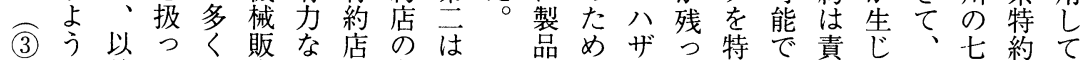
のに前ては壳商は多既をにはた約あ任て二地店お

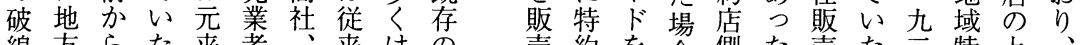

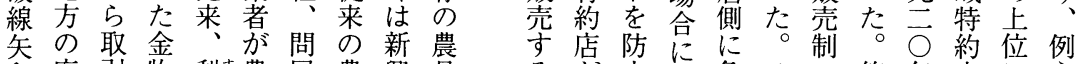

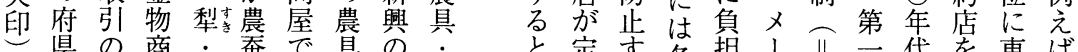

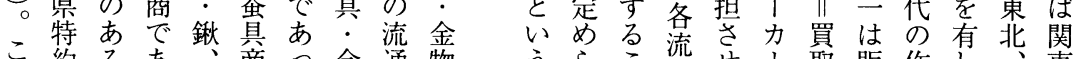

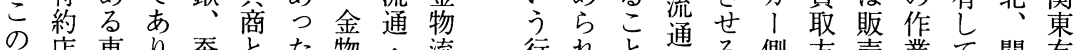
要店東り暻称た物流行れと通る側方簩業て関有 要や京、具称。な販通為た第階と热式管機い東数

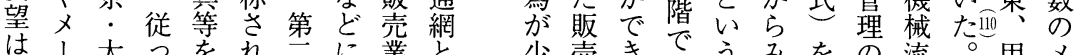

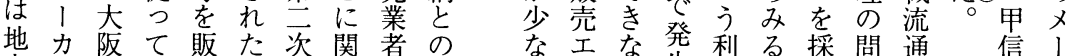

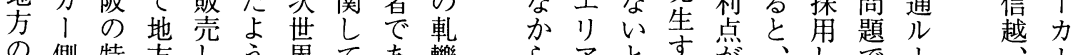

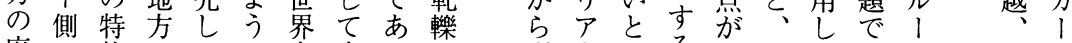
府に約のてに大自つでずをいるるあ責てあた 県要店有い、戦社たあ登越う可つ稚いるで部あ 特望を力た作後販がる。生え問能た貶た。は

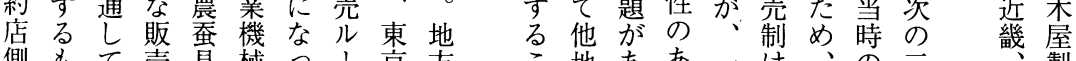

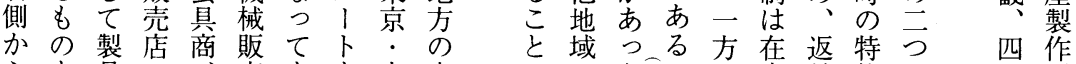

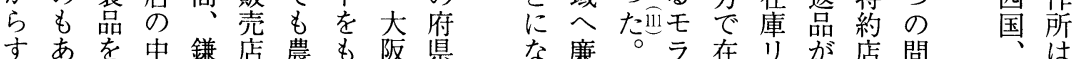

ジ係こメぞたにが消しじ細よ相でて 2 のだらは有よ察も強ば 力変の力て至る资あ みに

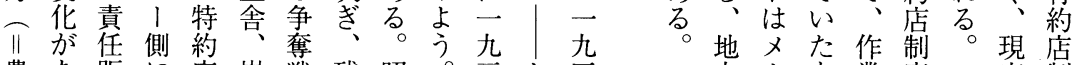
農あ販に店岩戦残昭。至七言方交業度穾制 村つ壳有の男がつ和第 $\vec{\bigcirc} ッ \vec{\bigcirc}$ に力の機の に度 へた制利囲兄展た恐年卜年立।の械下代を の。解ない弟開優慌の代販代 地側、流で 形

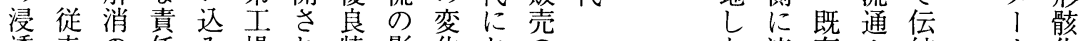
透来の任み場れ特影化おの 度、背販、䋨はけ展 有景売新木。店に特る開 機力に制規屋こによ約農と 械作はが取製れ対つ店業農 の業 メ撤り作まして 制 機 業 性機 I 廃込所でて在度械機 能械力さみな高は庫に流械 メメ1れにど額有を捅通 にとる奔の方抱けの門 絶力特こ走有保作之る変販 対 l 約とし力証業た責化売 のは店に、メ金機特任の店 自自のなそ!械約販実の 信社間つの力取 メ店売態登 をののた過、っはの制を場 持ブ力。程はてカ倒の追 た流存ル統岿化 中通の1 的 I 寸 小・農卜な側る 規販具は農はも 模 売流構具この 圣機通築商うで 場 能の主しあ のの経れ金たつ 全外党た物要た 国部資。商望方、 賠に鿌后再認既 をよ活二編好存 可る角 方禁流 能利すのる に益る問こた網 しを流題と網 ちラ関年こい1産解跡

たも通をに推力 
経営史学 第38巻第 1 号

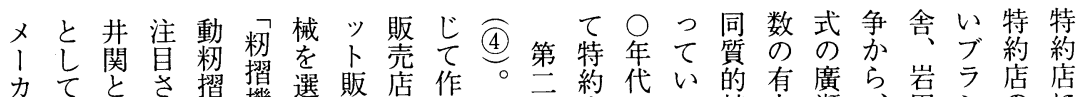

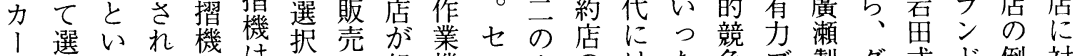
を択うる 選し作の全は保セ府卜合械卜化組特。のラ作・六力産し 択た業は保キ府ト合を唄は織約二中方所ヤ岩をにて るで械杉製登特はせ売と無を华店方でド実のホき胃持妿韭

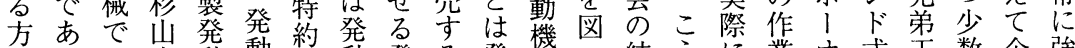
がるは商動動店動発る登機つ結うに業才式正数企強

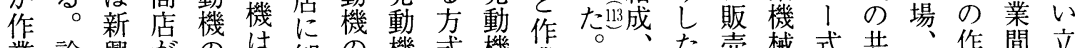
業論興㤎のは卸の機式機業 機理 メ性セク紫全と炎の采僟 械的।能ツボ罗箱る全械 のにカにト名は「総業る国械総の 声伝を定賠とな宗な理械従贷セ

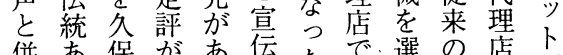
併あ保があ伝たで選農砉販 せる田あげさ有古択農ル販 杉力七たれた名商て機トの

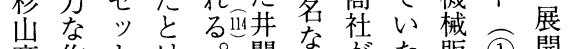

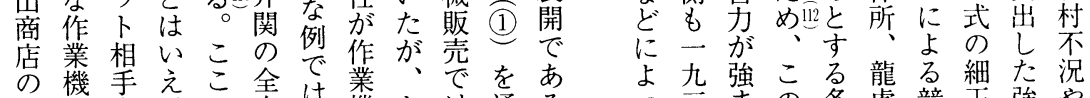

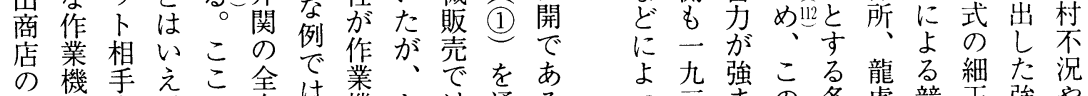

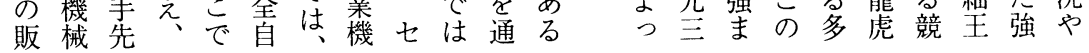

リ動をにの栄子業競場 べき担よ寺社 ヨ機争に 人に当る阪、名械のあ 卜対专競免瑞式 変? 制しる争弟光の例化た 度て 特に商式木え のメ約変会の屋㕖すと 充 1 店化を大製、なこ 実力のしは阪篗ミわろ 化、発たじ製所ノちが な側言ため作し儿突農

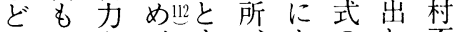
に一が、す、よのし不

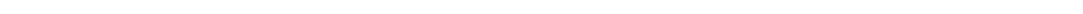

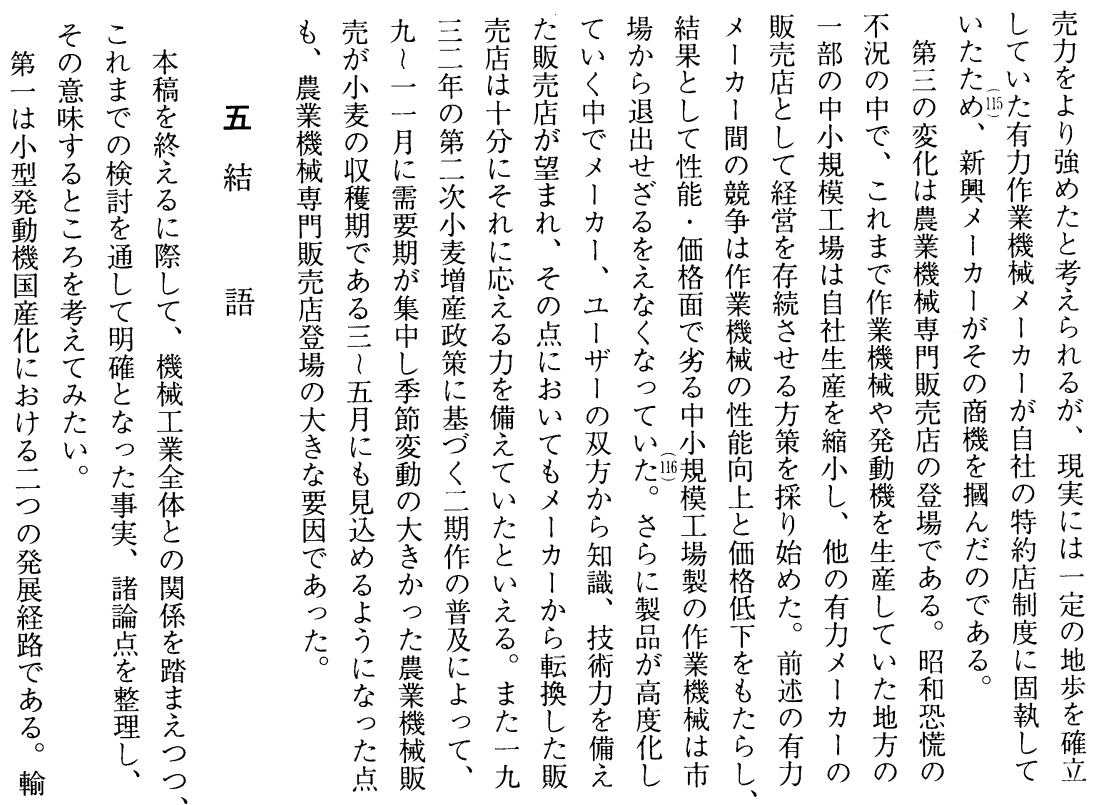




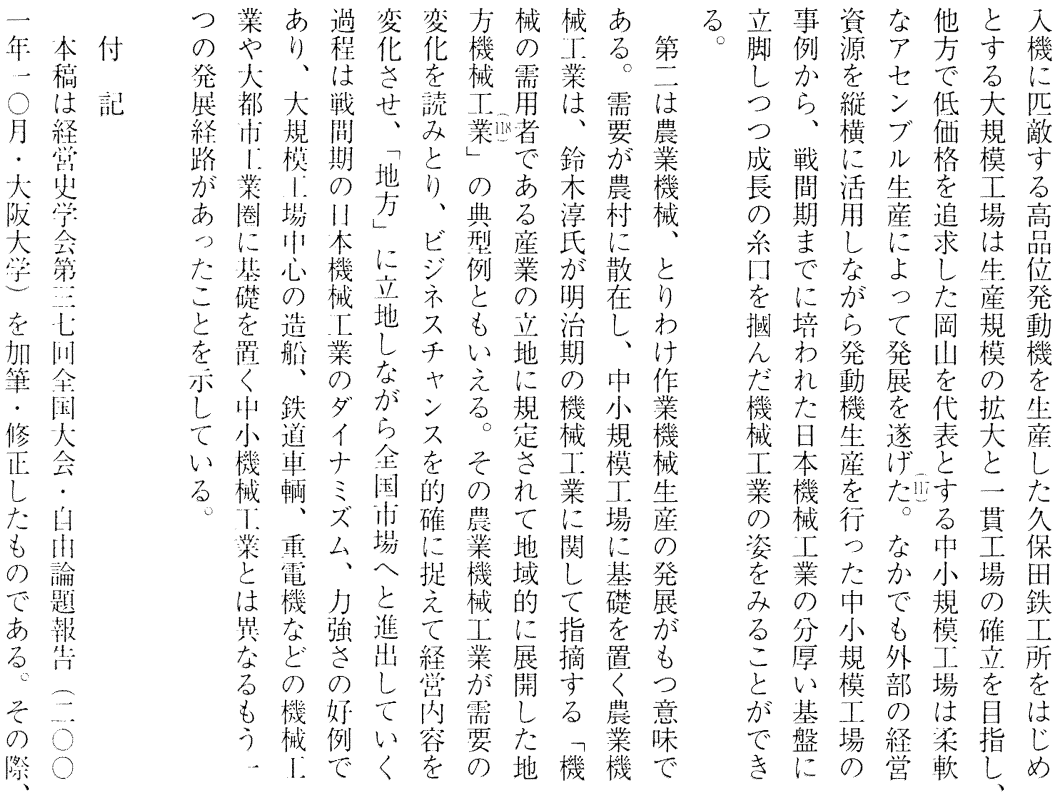

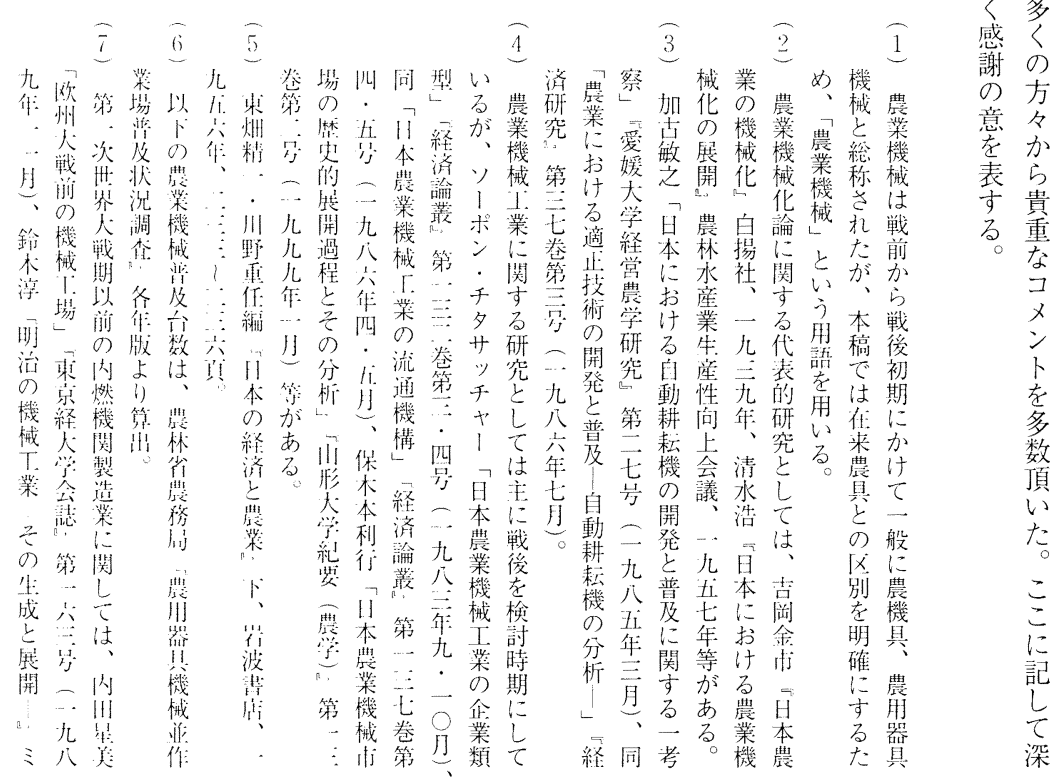


経営史学 第38巻第 1 号

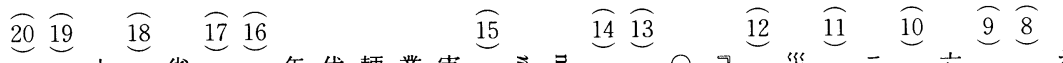

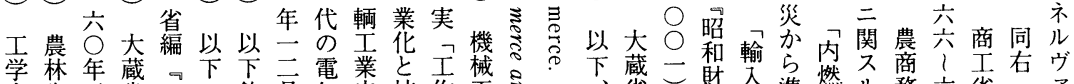

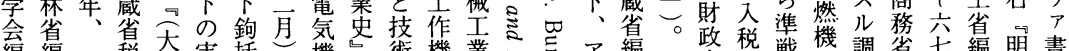

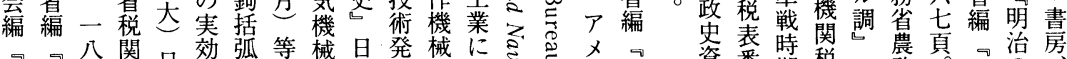

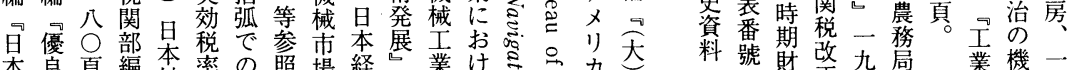

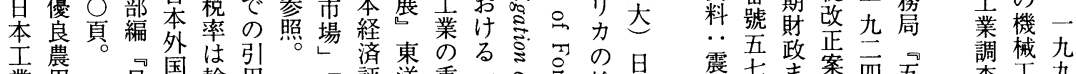

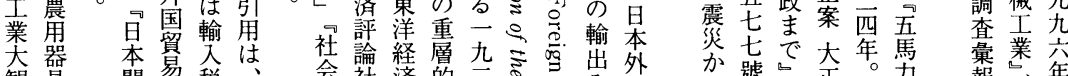
観其関等税、会社済的二而入国 工機税表收前

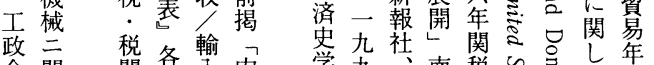
会関関各入内学九南税气事年

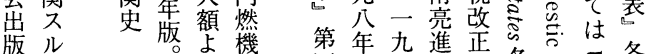
部調资算関五長七清意年〕版年

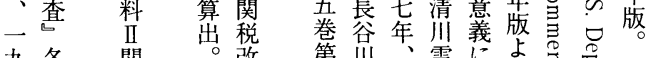

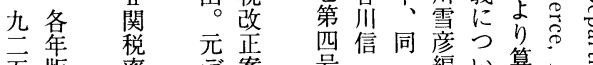

吾年版率完㱏号信同編い算子言

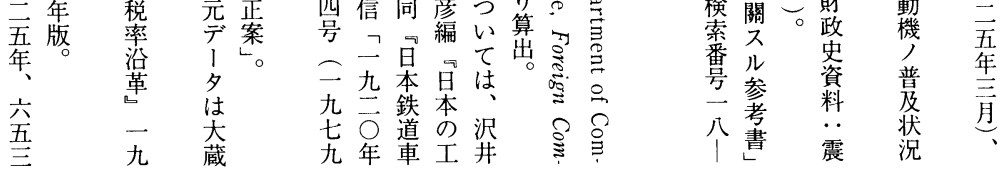

$\overparen{32} \widehat{31} \quad \widehat{30} \quad \widehat{29} \widetilde{28} \quad \widehat{27} \quad \widehat{26} \quad \widehat{25} \quad \widehat{24} \quad \widehat{23} \quad \widehat{22} \quad \widehat{21}$

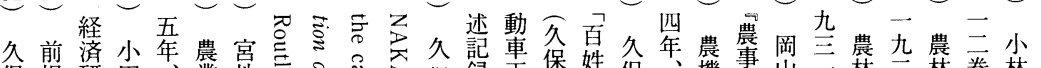

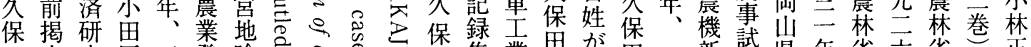

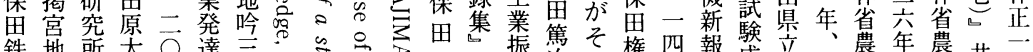

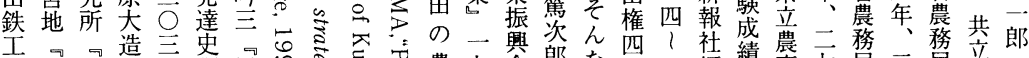

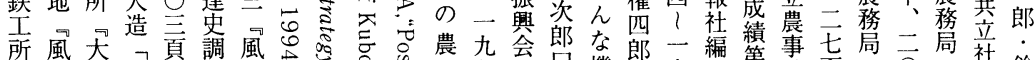

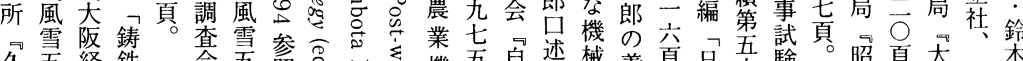

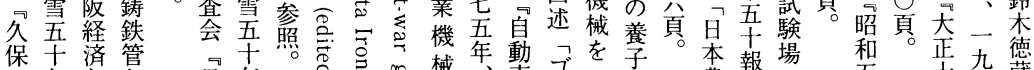
田年とお 鉄 ᄂ,機上 工四械び

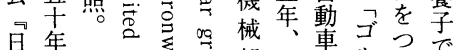

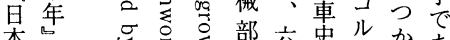

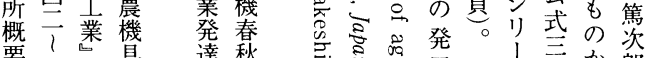
農農

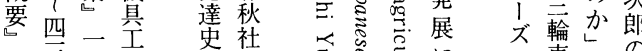
九頁五業立一

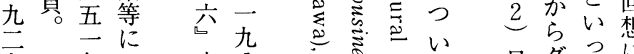

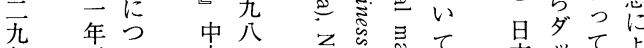

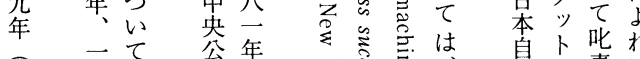

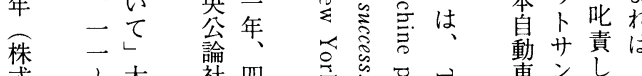

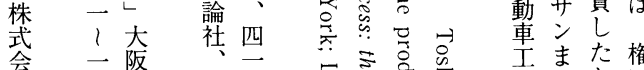

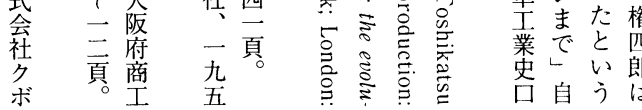

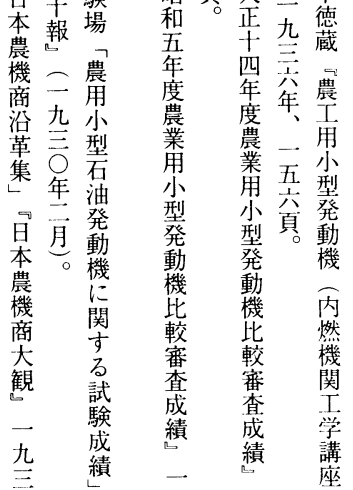




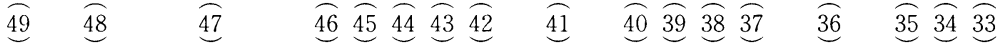

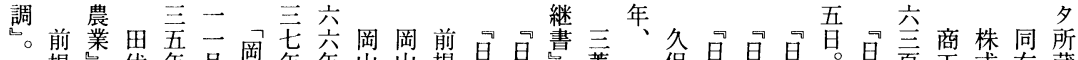

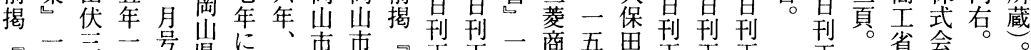
五九作

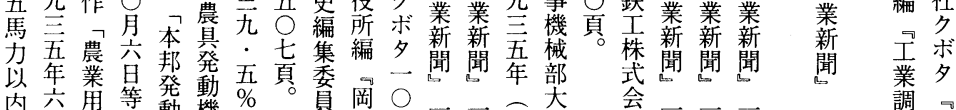

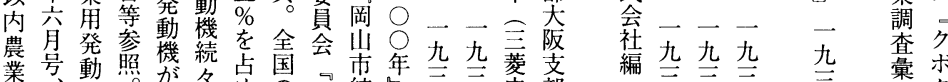

用:機南朝めの岡統以、三亥史部

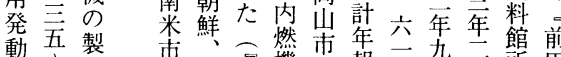

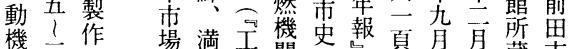

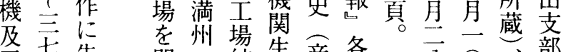

電貪先開へ統生産各年分心部

動頁鞭拓乞許産業年

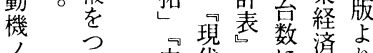

普け虫帒よに済り

是同商業算点岡出

洗崱新一出割山

斛県報九。合市

関現

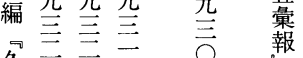

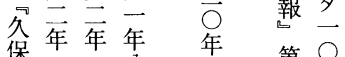

开二八公四第

鉄月五杂盟巻年

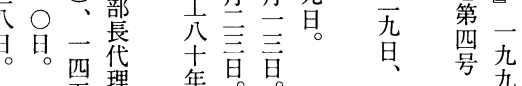

ル代九年九九

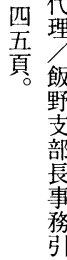

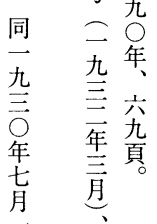

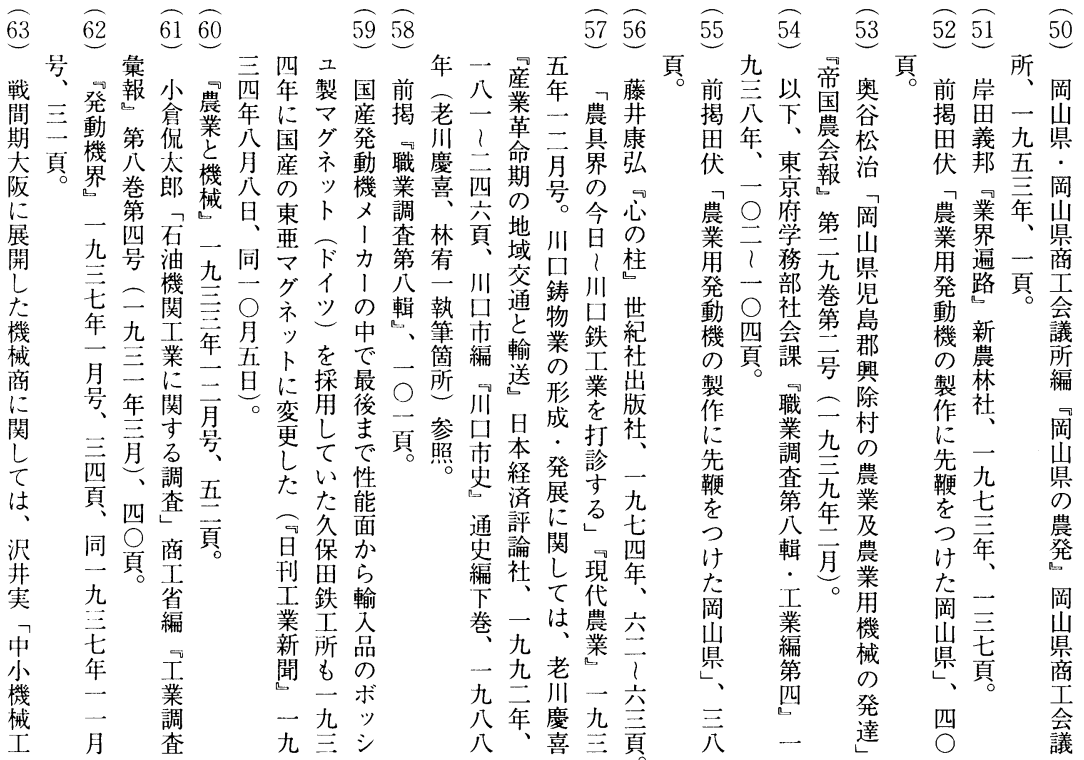




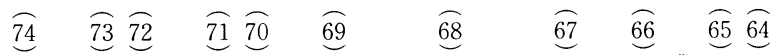

和一向表動九九究機者二ミ頁業号の業

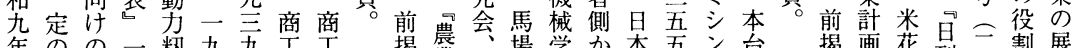

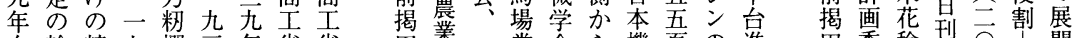
台輸精九摺至年省省思業一常会ら機頁の進田委稔刊 $\vec{\bigcirc}$ 開

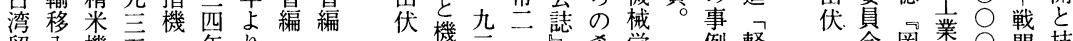

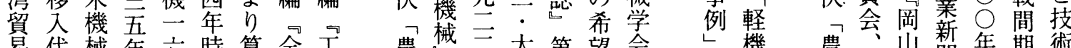

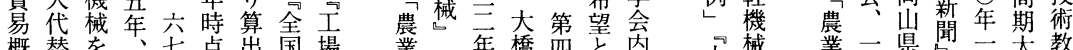

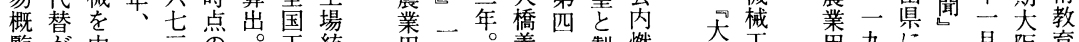

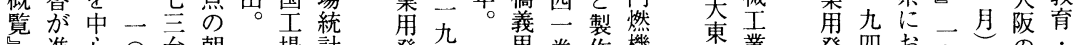
進心○台朝場計 一衍に九㔯鮮通表

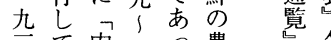

至い内—つ地一た㗼

年た品 $○$ 機

、可哭頁朝械和版

三能模頁鮮普 四

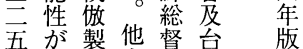

頁あ作方府数 る品台昭発

台頭湾和動 湾 総がは年七 督み类農吾 昭れ場計台

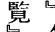

昭 年

四

年

日

刊

業

薪

社
登㤂男卷㤰機

動严最第者閏

製旨

作号

先六

を

け六

剛頁

直

県

三
最至側部

小八ら委

型号の員

発乞希会

動二望国

機九に国

解云心会

日年て 燃

本月の座関

小型、談に

登八会対

動五 る る

機 $\bigcirc$ 旦使
東業

花の

大登

学展

紀 部

要 㗊

第 規

言格

号準

工化

九 石

八 石
五 登
年 動

豆機
発四方九的台

動八け参事公

機年、百照例設

の、農年年機試

作六具二 只研

先頁業亘阪究

先鞭業二 大関

鞭奉白学・

態旦経機

けに済械

たり 学商

岡 第機

県四械

四㴊巻具

四 県 第商

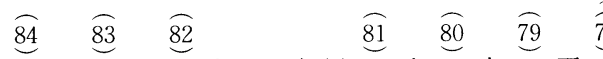

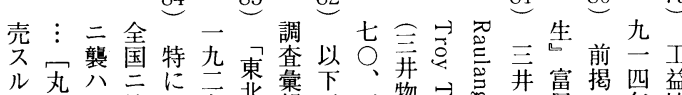

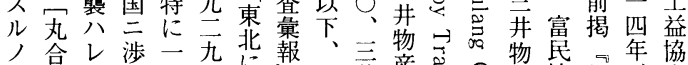

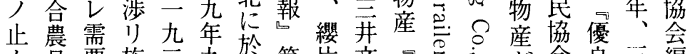

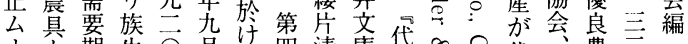

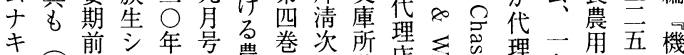

状筆ナ多下

洗者ルル期

で乼臬 $\vdots$ か

あ製於命九

た嵒宁略二

杂格既

合多乱辞

㖘㔛小期

具テ分製は

製甚態造

造焉客

株キ者年

式低：最,

会位 販 好

社平売況

第立略者蓞

参販 $\vdots$ 怖

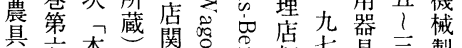
界公本。牦吕契七具要製 の号邦製る寻約杂機云造 重二おに造で哥を年械貪啠

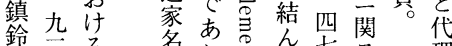

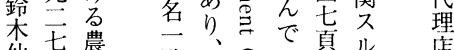
仙年業 次三機 郎百械 逝に業至国总四和年

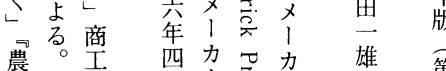
業省 機
覧全○い頁調店

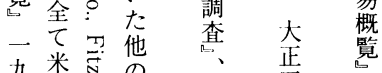
月只竞は 耕第

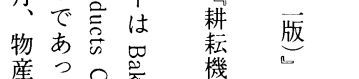

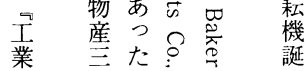

頁

参類米㣽以参照農 蔵他考細国宫紫 省心に分貿怘。 悦の耕さ統茺国

吾作れ計: 国

編分頪るに各輸 類械。书年出編 大实械、本け版出部 正再 稿るよ関編 芷集简で作り関 年計 ラは業算名 外し夕統機出る 国た多計械 貿、のは ! 算々、連初多㱉 ‘連衫は学 覽収性の

穫公 機白分 九械本類 調農 最 調整機聚 整機械 械分至 


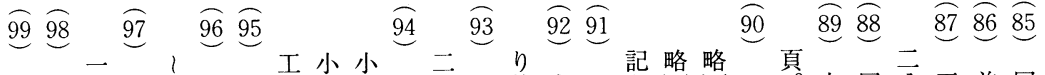

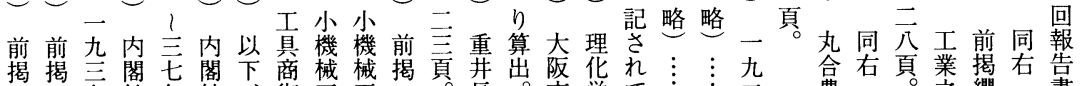

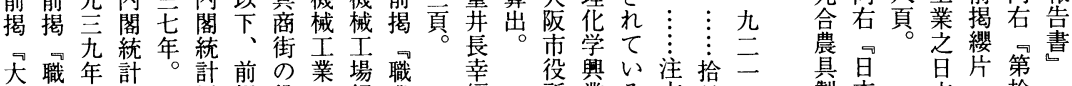
阪業よ梮梮揭役の経業 市調り 割展党調 工查算昭労職害開著查 業第出和华業が炎鼻第 党輯三三梳調ある術キ公輯

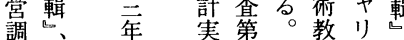
查八 臨地八輯育亲時 意六学 查輯、公関无 三 報一設公 告正試る九 九

八 塞 第六 挽研究 回二 究气 機

九 查

頁 報 四 面

機 前の

編所業る文肙年

留簓合公中下

早龺阪局旦句期

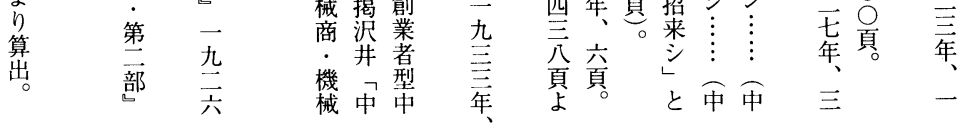

械揭 創

農市追当営

機恶最第告夜掌

具業近五テ業報

界経の回激丵報

發嫦農報增開告

録查機畫延始に

查機書延始に

書械一㰾は

農業九製善職

九究努工

四一云㠰努

械

年夳年、否召 增

製本本拾一

造 工 社本武九

株業編帮回致

会爁可お㱉年

社第本溊三

第第 撲農書

拾九要業四

吕版鑑機元頁。

掌而第業吾

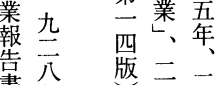

書年版三三

九 $\overrightarrow{0}$ 九产

四年頁招 シ

年頁言頞

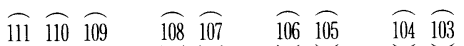
五、本前七井岩年金前岸前、い鉄組一商杉品機ナ地金生外以 年農屋揭頁関田、岚揭

一具製岩。帮継二愛宮

一分作早兰清宍次地 号貶売 春 郎春頁郎風

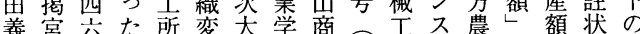
義宮公た所変戰学商三業等事同に洗下 方寺継型継金雪 居淘

販年録

㣦息淘洒

党史、、会息歩四 䆩録年年

者二言

ら六

関欪だて

聴 六

帮版、道四

農風頁帝藤乞期卒社 $○$ 登深試書点調請

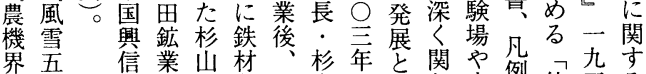

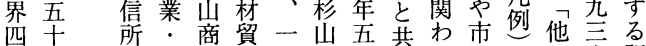

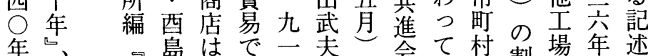

年

関製はで成恶は参会て䀼割場に年速

潮至西作九功年一照試た会拿註よ 流貟鎅所公收神分験詳農る交る商

新人総年めの○

場詳農る。广な文

の

郎云金鿓

会頞

現

公吾

農

農一物代にた金年

大理大。物滋

観店阪一商賀

第とに九胗県

九 第し本立崇生

集事を年のま

帒

兰六会

業

年

九

忿

業移に養れ、

九搪、頜学神

Fi

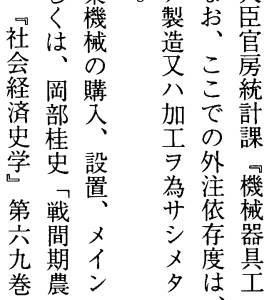


経営史学 第38巻第 1 号

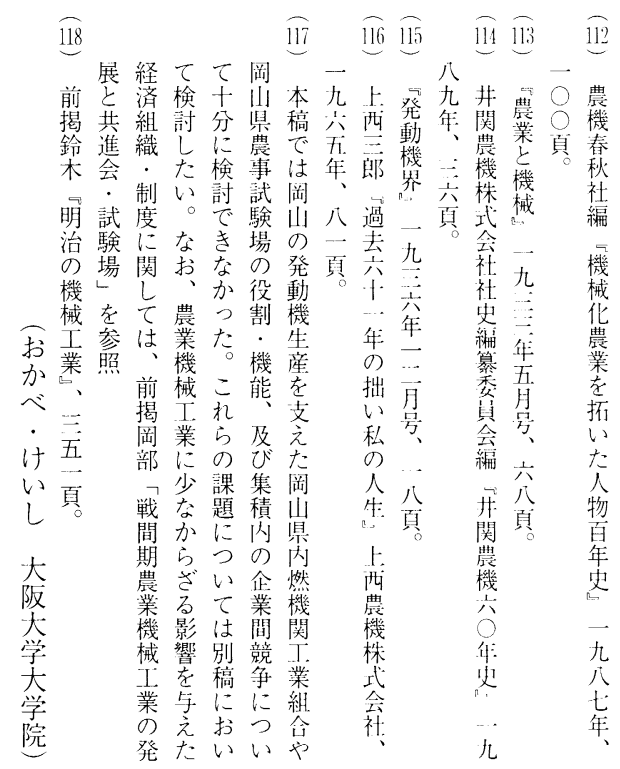




\title{
THE DEVELOPMENT OF THE JAPANESE AGRICULTURAL MACHINE INDUSTRY DURING INTERWAR PERIOD
}

\author{
Keishi Okabe \\ Osaka University
}

The purpose of this paper is to clarify the development process of the Japanese agricultural machine industry during the interwar period. The historical significance of the agricultural machine industry has been mainly studied in the fields of agricultural and industrial technology. This paper is the first attempt to evaluate it form the viewpoint of the industrial and business history.

Unlike the American agricultural machine, which had developed from reapers or the tractors, the growth of the Japanese agricultural machines before World War II was led by the development of threshers and hulling machines. We can confirm the progress of agricultural mechanization by small machines. One characteristic of Japanese agriculture is the large number of petty farmers whose diversified small tenable lots made agricultural mechanization by large-sized machines impossible. Big firms like International Harvester in the United States manufactured both engines and machines, but in Japan, each factory specialized in the production of engines or machines (threshers and hulling machines). In this paper, therefore, the petrol engines and agricultural machines are examined separately.

The increase in the production of petrol engines was led by both big factories such as Kubota Ironwork, and small- and medium-sized factories (e.g., the network of small factories in Okayama city). In the case of agricultural machines, they established their own production embedded in agricultural implements in the 1920s. Lastly, the distribution system, evolved from dependence on indigenous implements and hardware distribution in the 1920 s to a new system supported by dealers specializing in engines and agricultural machines in the 1930s. 